\title{
THE GENESIS AND CLASSIFICATION OF MOUNTAIN SOILS DEVELOPED ON TUFFS IN INDONESIA ${ }^{1}$ )
}

\author{
J. VAN SCHUYLENBORGH and F. F. F. E. VAN RUMMELEN
}

\section{SUMMARY}

In order to ascertain the genesis and arrive at a classification of the so-called "mountain soils" of Indonesia, developed on tuffs, a large number of profiles (37 in all) were dug, of soils situated at heights between 700 and $2000 \mathrm{~m}$ above sea level. After the profiles had been described as accurately as possible, samples of the various horizons were taken and examined in field-wet condition in the laboratory.

As only those profiles in which no fresh admixtures or coverings of ash could be detected were eligible for genetic consideration, seven serviceable profiles remained, of which four are discussed here.

The laboratory examination consisted in determination of : 1. texture; 2 . the grain size distribution of the sand fraction; 3 . the mineralogical composition of the sand and clay fractions; 4 . acidity; 5 . organic matter content; 6 . the chemical composition of the clay fraction.

From the descriptions of the profiles and the results of these analyses the following conclusions were drawn.

A. In Indonesia, at altitudes between 700 and $2000 \mathrm{~m}$, brown podzolic soils are formed on liparitic tuffs, grey-brown podzolic soils on andesitic tuffs, and brown forest soils on basalto-andesitic tuffs. The parent material therefore proved to exert a predominant influence on the groups of soils formed. The climate is very humid in all cases. As the clay minerals of the tropical "mountain soils" are of the $1: 1$ type of crystal lattice, and those of the similar soils in America are of the 2:1 type, it will perhaps be necessary to speak of "tropical grey-brown podzolic" and "tropical brown forest" soils, when dealing with the tropics.

B. As, in America, such soils occur respectively on acid to weakly calcareous, on basic calcareous, and on basic strongly calcareous parent materials, and under temperate climatic conditions, the explanation for the occurrence of the same soil groups has been sought in a difference in the nature of the weathering agent.

The results of (1) an examination of the $\mathrm{C} / \mathrm{N}$ quotient of the organic matter in the horizons of the profiles and of (2) an examination of the rainfall/evapotranspiration quotient made it feasible to assume that the soils in question are formed in Indonesia under the influence of water containing $\mathrm{CO}_{2}$, and in America under the influence of a relatively concentrated solution of organic acids.

The conclusion was drawn that in Indonesia weathering admittedly takes place very quickly, but less intensively than in the temperate zones.

The difference in the nature of the weathering agent also explains the fact that, under tropical conditions, at altitudes of from 700 to $2000 \mathrm{~m}$ aluminium is more mobile than iron, whereas the reverse is the case in temperate climates.

\section{INTRODUCTION}

The "mountain soils", occurring at heights of from $600 \mathrm{~m}$ to $2000 \mathrm{~m}$ above sea level in the East Indian Archipelago cover a substantial part of its surface. They occupy on Java 21.950 square kilometres, or $17 \%$ of the entire area of the island (MoHr and VAN Baren, 1954, p. 289).

Despite the fact that a considerable proportion of the above-mentioned soils functions as a nutrient medium for the highly important mountain cultures, little is known about them, especially as regards their genesis and classification.

1) Received for publication June 27, 1955. 
This is evidenced by their virtually meaningless name of "mountain soils", the expressiveness of which is certainly not enhanced by the fact that the soils are developed on ejectamenta and effusive rocks, and on other parent materials, including limestone.

Only one investigation of mountain soils in Indonesia is known to have been carried out, namely, that of Senstius (1930), who endeavoured to substantiate by means of analyses the ideas of Morr (embodied in the book "De bodem van Java en Sumatra" (1922)), but without arriving at a definite system of classification. However, this investigation of SENSTius relates to only three profiles, viz., those of Gunung Lawu and Gunung Malabar in Java, and that of Gunung Banahao in Luzon (Philippines), which, moreover, originated from points more than $2000 \mathrm{~m}$ above sea level. Nevertheless, he does come to the conclusion that podzolic weathering is involved.

Accordingly, it seemed desirable to carry out an investigation into the origir. and properties of the above-mentioned soils - a procedure which seemed all the more justified because even in the new book by MoHr and VAN BAREN (1954) there is a gap as regards this subject.

The present investigation is confined to those soils which have originated from ejectamenta. To this end, profiles were dug and sampled at a fairly large number of points in Sumatra and Java. In doing this, careful attention was devoted to the autochthony of the profiles. This question is fraught with great difficulties, as it is frequently impossible to conclude from observation of a profile whether a magma differentiation has taken place during periods of eruption or whether ash products have blown in from other volcanoes, which may have been situated at great distances away from the profile examined. Moreover, the mineralogical composition of all Indonesian volcanoes in their periods of eruption is not known. Investigations (BAAK, 1948, 1949; VAN RUMMELEN and RACHMAT, 1952; VAN RUMMELEN, 1953) have, however, shown that the recent volcanic eruptions possess their own characteristic mineralogical composition. Accordingly, a large number of profiles had to be sampled in order eventually to obtain a reasonable number of them for the purpose of the investigation. Further attention will be given to this point in the section on Description of Profiles.

Finally, the following profiles were subjected to further soil-genetic examination: Sumatra: Tapanunli (Aek Na Uli); Java: Leuwiliang (Tjianten); Pudjon; Djunggo (Gunung Ardjuno).

\section{DESCRIPTION OF PROFILES}

Before the profiles are described, the following procedure must be carried out :

A. the criteria to be applied in judging whether a profile has not been obscured by, for instance, strong admixtures of ash, erosion, or in other ways, should be discussed;

B. the climate should be described.

A. Selection of profiles. The profiles were taken, as far as was possible, from points overgrown with natural vegetation, and hence erosion will, a priori, be of little significance in them. In cases in which natural vegetation was 
absent, only those profiles were sampled which showed no signs of erosion.

Strong admixtures of ash also constituted a reason for regarding the profiles concerned as unsuitable. Logically considered, such admixtures must manifest themselves in :

1 a capricious pattern of the mechanical composition (texture) of the various horizons in the profile,

2 a capricious change in the mineral composition of the sand fraction. The relative proportions of the components in any one association must not exhibit any stronger fluctuations than are in conformity with the resistance of the minerals to weathering. Nor may the mineral association itself change to any great extent.

Furthermore, the demand is made that the humus content should normally decrease with depth. This condition is imposed because the climate, and hence also the vegetation, differs at altitudes between $600 \mathrm{~m}$ and $2000 \mathrm{~m}$ from the climatic and vegetation conditions in which genuine podzols are formed. Only genuine podzols, and of those, again, only the humus podzols, exhibit a humus enrichment in the $B$ horizon.

If a profile failed to satisfy these demands it was eliminated from the investigation ${ }^{2}$ ).

B. Climate. At the altitudes mentioned the average annual temperatures vary from $20^{\circ} \mathrm{C}$ to $13^{\circ} \mathrm{C}$, with only slight seasonal fluctuations. Morr and VAN BAREN (1954) classify these temperatures as moderately warm to temperate; KNoch (1929) and Schauffelberger (1950) regard them as temperate in the cases of Guatemala and Colombia respectively.

In the regions examined the mean rainfall varies from $2123 \mathrm{~mm}$ to $5420 \mathrm{~mm}$ per year. As a tropical forest at the altitude in question evaporates about $1000 \mathrm{~mm}$ per year (CosTeR, 1937), it can be concluded that a practically constant movement of water occurs downwards through the profile. Distribution of the rainfall throughout the year differs decidedly in the regions concerned. In Tapanuli there are only two fairly dry months, viz. June and July. West Java has no dry months : the rainfall is very evenly distributed. Central Java, on the other hand, is characterized by a rather pronounced dry season in July, August and September, while East Java passes through a reasonably dry period in the months from June to September inclusive. Further details are given with the profile descriptions.

As a result of these circumstances the movement of water can be indicated by DD (see Mohr and VAN BAREN, 1954, pp. 292, 293).

\section{Descriptions of profiles.}

1 Residency: Tapanuli. Department: Tarutung. District : Balige. Aek Na Uli (Samples Nos. 147-151).

Altitude : $1300 \mathrm{~m}$. Topography : flat top of mountain.

Vegetation: pine plantation. Originally tropical mountain forest.

2) The data concerning the eliminated profiles are obtainable from the first of the present two authors. 
Rainfall : $2609 \mathrm{~mm}$. Monthly distribution of rainfall (BERLAGE, 1949) in mm: Jan. Feb. March April May June July Aug. Sept. Oct. Nov. Dec. $\begin{array}{llllllllllll}223 & 146 & 258 & 262 & 183 & 78 & 51 & 165 & 282 & 373 & 279 & 309\end{array}$ Parent material : liparite tuff.

$\mathrm{A}_{00} \quad 5-0 \quad \mathrm{~cm}$ Pine needle litter. Stratified.

$\mathrm{A}_{1} \quad$ 0-10 $\mathrm{cm}$ Dark grey ${ }^{3}$ ) to black (Munsell : 10YR3/1-10YR2/1) clay loam. Many roots. Nutty structure.

$\mathrm{A}_{2}$ 10-20 $\mathrm{cm}$ Brown to dark reddish-brown (Munsell : 10YR5/3-5YR3/4) clay loam. Many roots. Nutty structure.

B $\quad 20-75 \mathrm{~cm}$ Reddish-yellow (MunseLL : 7.5YR8/6-5YR6/8) clay loam. Few roots. Clod structure.

$\mathrm{C}_{1} \quad 75-90 \mathrm{~cm}$ Pale brown to light yellowish-brown (Munsell : 10YR8/310YR6/4) sandy loam. Granular structure.

$\mathrm{C}_{2} 90+\mathrm{cm}$ White to pale brown (Munsell: 10YR8/2-10YR6/3) sandy loam. Granular structure. Liparite tuff.

2 Residency : Bogor. Department : Bogor. District : Leuwiliang. Gunung Kendeng. Tjianten plantation (Samples Nos. 308-312).

Altitude : $1000 \mathrm{~m}$. Topography : flat top of Gunung Tandjungsari.

Vegetation: tropical mountain forest, somewhat thinned out (including Altingia excelsa Nor, Magnolia spec., Astanea spec., Podocarpus spec., Calophyllum Teysmanni Zoll. et Nor; Glochidion spec., etc.).

Monthly distribution of rainfall in $\mathrm{mm}$ :

Jan. Feb. March April May June July Aug. Sept. Oct. Nov. Dec. $\begin{array}{llllllllllll}432 & 453 & 472 & 538 & 497 & 350 & 290 & 338 & 464 & 583 & 576 & 460\end{array}$

Parent material : andesite tuff.

$A_{00} \quad 2-0 \quad \mathrm{~cm}$ Layer of organic matter of mull type.

$\mathrm{A}_{1}$ 0-15 $\mathrm{cm}$ Very dark brown to very dark greyish-brown (MunseiL : 10YR3/3-10YR3/2) loam. Very many roots. Coarsely crumbly to nutty structure.

$\mathrm{A}_{2} \quad$ 15-28 cm Dark brown (Munsell : 10YR4/3) silt loam. Many roots. Nutty structure.

$\mathrm{B}_{1} \quad 28-46 \mathrm{~cm}$ Dark yellowish-brown (Munsell : 10YR4/4) loam. Many roots. Rather more compact structure. Some residues of weathered tuff present.

$\mathrm{B}_{2} \quad 46-66 \mathrm{~cm}$ Yellowish-brown (MunselL: 10YR5/4-10YR5/6) loam. Fair number of roots. Fairly loose structure. Rather more weathered tuff residues.

C $66+\mathrm{cm}$ Yellow to brownish-yellow (MUNSELL: 10YR7/8-10YR6/8) sandy loam. Few roots. Very loose structure. Strongly weathered pumice tuff.

3 Residency: Pasuruan. Between Pudjon and Tretes. Situated on ridge between Gunung Butak-Kawi and the Andjasmoro Mountains. (Samples Nos. 93-97).

3) The colours indicate dry and field-wet samples respectively. 
Altitude : $1000 \mathrm{~m}$.

Vegetation : secondary bush. Rainfall : $2123 \mathrm{~mm}$ per year. Monthly distribution of rainfall in $\mathrm{mm}$ :

Jan. Feb. March April May June July Aug. Sept. Oct. Nov. Dec.

$\begin{array}{llllllllllll}360 & 376 & 289 & 171 & 87 & 68 & 29 & 30 & 46 & 115 & 240 & 312\end{array}$

Parent material : andesite tuff.

$\mathrm{A}_{11}$ 0-14 $\mathrm{cm}$. Pale brown to dark brown (Munsell : 10YR6/3-7.5YR3/2) loam. Many roots. Loose granular structure.

A 12 14-30 cm Pale brown to dark brown (Munsell: 10YR6/3-10YR3/4) loam. Many roots. Loose granular structure.

$\mathrm{A}_{2} \quad 30-55 \mathrm{~cm}$ Light grey to dark reddish-grey (MUNSELL : 10YR7/2-5YR4/2) loam. Very loose granular structure.

B 55-70 cm Pale brown to dark reddish-brown (Munsell : 10YR6/35YR3/4) loam. Fairly compact structure. Next to no roots.

$\mathrm{C} \quad 70+\mathrm{cm}$ Very pale brown to light yellowish-brown (Munseln : 10YR8/310YR6/4) sandy loam. Fairly loose, granular structure. No roots.

4 Residency : Pasuruan. Batu. Djunggo. Slope of Gunung Ardjuno (Samples Nos. 233-237).

Altitude : $1200 \mathrm{~m}$. Topography : almost flat part of the south-west side of Gunung Ardjuno.

Vegetation : tropical mountain forest. Rainfall : $2542 \mathrm{~mm}$ per year. Monthly distribution of rainfall in $\mathrm{mm}$ :

Jan. Feb. March April May June July Aug. Sept. Oct. Nov. Dec. $\begin{array}{llllllllllll}400 & 362 & 341 & 222 & 181 & 105 & 60 & 45 & 44 & 136 & 282 & 364\end{array}$ Parent material : basalto-andesitic tuff.

$A_{00} \quad 12-0 \mathrm{~cm}$ Litter. The bottom $3 \mathrm{~cm}$ well decomposed; mull type.

$A_{11}$ 0-16 cm Dark grey to black (Munsell: 10YR4/1-10YR2/1) loam. Many roots. Nutty structure.

A 12 16-25 cm Dark greyish-brown to black (Munselu : 2.5Y4/2-2.5Y2/0) loam. Many roots. Crumbly structure.

B 25-38 cm Brown-very dark greyish-brown (MunselL: 10YR5/3-10YR3/2) silt loam. Rather loose crumbly structure. Fair number of roots.

$\mathrm{A}^{\prime}{ }_{11}$ 38-63 $\mathrm{cm}$ Dark brown to very dark brown (Munsell : 10YR4/310YR2/2) silt loam. Compact structure. No roots.

$\mathrm{A}^{\prime}{ }_{12} 63+\mathrm{cm}$ Brown to dark reddish-brown (MunselL : 10YR5/3-5YR3/3) silt loam. Looser granular structure. No roots.

The difference in designation of the various horizons is due to the fact that the results of the analyses (see p. 202) indicate the presence of a double profile. In that case $\mathrm{A}_{11}^{\prime}$ must have been a former surface horizon which later became covered with a new layer of tuff.

Methods. The following were determined in succession :

1 granular composition;

2 mineralogical composition of the sand and clay fractions;

3 acidity;

196 
4 content of organic matter;

5 chemical composition of the clay fraction.

1. Granular composition. Investigation of this factor is fraught with two very great difficulties in the case of the mountain soils. In the first place, it is inadmissible to dry the soils in question at the air beforehand (VAN ScinurLENBORGH, 1954), as this results in very pronounced changes in its physical condition. For that reason the samples from the profiles described above were treated in field-wet condition, as far as was possible.

In the second place, peptization of the oxidized soil is no simple matter. Some profiles (those from Tapanuli, in particular) were best peptized with sodium pyrophosphate; others (e.g., those of Java) were most satisfactorily peptized with highly diluted hydrochloric acid. In that respect, differences were present even within one and the same profile. This made it necessary to find the most suitable peptization agent for each individual horizon. In doing this it was found that, in most cases, peptization in a solution of 0.005 $N \mathrm{HCl}$ was best. In the other cases a 0.0003 mol. sodium pyrophosphate solution achieved the most satisfactory peptization. It is a very remarkable fact in itself that hydrochloric acid should be the most suitable peptization agent for most of the mountain soils examined. This was in complete correlation with the $\mathrm{X}$-ray diffraction photographs of the clay fraction. The samples exhibiting sharp diffraction lines had to be peptized with pyrophosphate, and those exhibiting vaguely defined, diffuse lines had to be peptized with hydrochloric acid. Since no detailed investigation of this phenomenon was carried out, discussion of it here would be premature.

The analysis as such was performed by the customary pipette method, after the fraction larger than $44 \mu$ had been removed by sieving.

The result of this analysis enabled the soil type to be classified.

2. The mineralogical examination. In order to ascertain grain distribution the separated sand fraction was sieved by means of the Rotap sieve apparatus. The ranges of the five sand fractions were as follows : $2000-500 \mu ; 500-250 \mu$; $250-105 \mu ; 105-53 \mu ; 53-44 \mu$. In all fractions the minerals were counted according to the normal line-counting method. Thereafter the fractions were combined and separated by means of bromoform with a s.g. of 2.90 . The heavy minerals thus obtained were also counted.

The results yielded indications of the nature of the material, its weathering condition, its origin, and admixtures of ash if any.

The clay fraction (fraction $<2 \mu$ ) was separated by centrifuging, dried on a water bath, and subjected to $\mathrm{X}$-ray examination. For this examination the fairly simple PhiLIPs type 11704/23 instrument was employed. A $\mathrm{Cu}$ anode was generally utilized, or in some cases a Mo or Co anode, all according to the composition of the clay. The type of film used was Kodak X-ray film. All diagrams were necessarily powder diagrams. The $\mathrm{d}$ values were deduced by means of the nomograms designed by PARrish and ERwIN (1952), and consequently, after reference to the tables of HaNawalt (1950), it was possible to ascertain the components of the clay. Owing to the lack of adequate electronic equipment the intensity of the lines was determined visually; hence, after comparison with diagrams of known mixtures of minerals, it was possible to obtain a semi-quantitative result. 
3. Measurement of acidity. Very recent investigations have shown that the magnitude $\mathrm{pH}$, which is anything but easy to define sharply by physicochemical methods, is just as difficult to determine exactly in clay suspensions. Reference should be made to the investigation of BLoksma (1955) for a summary of the difficulties. The greatest obstacle to measuring $\mathrm{pH}$ is the occurrence of the suspension effect, the result of which is to make it uncertain whether the measured $\mathrm{pH}$ corresponds with the $\mathrm{pH}$ prevailing in reality. In order to obviate this effect the following procedure was carried out. A quantity of $10 \mathrm{~g}$ of soil was shaken for 12 hours with $25 \mathrm{cc}$ of distilled water. The suspension was then allowed to stand overnight. The clear supernatant liquid was then decanted, and its $\mathrm{pH}$ determined (the $\mathrm{pH}$ of this liquid must be the same as that of the soil that has settled). The instrument used was the Philips $\mathrm{pH}$ meter of the GM4491 type, while the glass electrode was chosen as hydrogen electrode, and the saturated calomel electrode was chosen as reference electrode. The measuring cell was a MonTon measuring cell.

4. Determination of organic matter content. This was carried out according to the AlLison method (1935). As, at the beginning of the investigation, the writers had no sodium fluoride at their disposal for the purpose of binding the ferri-ion complex, concentrated phosphoric acid was used. It was later found that this yields the same results as sodium fluoride.

5. Analysis of the chemical composition of the clay. This was carried out in its entirety, as described by Biltz and BiLtz (1947, p. 380. et seq.), the iron content being determined titrimetrically according to the method of ZIMMERMANN-REINHARDT $(1881,1889)$, and the phosphate gravimetrically after LoRENZ (1907). The aluminium content was not determined directly, but by subtraction.

In conclusion, it must be mentioned that all results were expressed as percentages of the soil or clay dried at $105^{\circ} \mathrm{C}$.

Results ${ }^{4}$ ). The results obtained in respect of each profile are given below in table form, together with further comments.

Profile I

Table 1.

\begin{tabular}{|c|c|c|c|c|c|c|c|c|c|c|c|c|c|c|}
\hline \multicolumn{8}{|c|}{$\begin{array}{l}\text { Chief minerals in the total } \\
\text { sand fraction }\end{array}$} & \multicolumn{7}{|c|}{$\begin{array}{c}\text { Composition of heavy sand } \\
\text { fraction }\end{array}$} \\
\hline \multirow{2}{*}{ 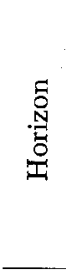 } & \multirow{2}{*}{$\stackrel{N}{\tilde{Z}}$} & \multirow{2}{*}{ : } & \multirow{2}{*}{ 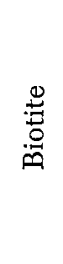 } & \multirow{2}{*}{ 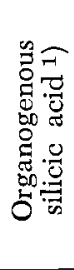 } & \multirow{2}{*}{ 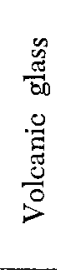 } & \multirow{2}{*}{ 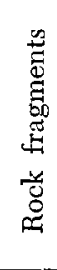 } & \multirow{2}{*}{ 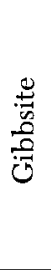 } & \multirow{2}{*}{ 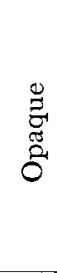 } & \multicolumn{6}{|c|}{$\begin{array}{l}\text { Content of non-opaque minerals } \\
\text { (as percentages of total content } \\
\text { of non-opaque minerals) }\end{array}$} \\
\hline & & & & & & & & & 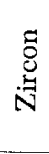 & 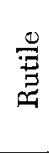 & 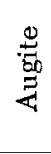 & 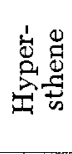 & 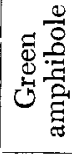 & 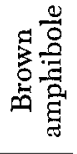 \\
\hline \multirow{5}{*}{$\begin{array}{l}\mathrm{A}_{1} \\
\mathrm{~A}_{2} \\
\mathrm{~B} \\
\mathrm{C}_{1} \\
\mathrm{C}_{2}\end{array}$} & \multirow{5}{*}{$\begin{array}{l}37 \\
34 \\
33 \\
14 \\
13\end{array}$} & \multirow{5}{*}{$\begin{array}{r}23 \\
24 \\
19 \\
5 \\
7\end{array}$} & \multirow{5}{*}{$\begin{array}{r}3 \\
8 \\
7 \\
30 \\
14\end{array}$} & \multirow{5}{*}{$\begin{array}{r}4 \\
3 \\
\text { tr. } \\
- \\
-\end{array}$} & \multirow{5}{*}{$\begin{array}{r}3 \\
3 \\
2 \\
2 \\
14\end{array}$} & \multirow{5}{*}{$\begin{array}{r}12 \\
6 \\
13 \\
27 \\
44\end{array}$} & \multirow{5}{*}{$\begin{array}{r}\text { tr. } \\
\text { tr. } \\
\text { tr. } \\
8 \\
6\end{array}$} & \multirow{5}{*}{$\begin{array}{l}46 \\
52 \\
49 \\
70 \\
89\end{array}$} & 28 & - & 2 & 19 & 50 & 1 \\
\hline & & & & & & & & & 30 & 1 & - & 15 & 54 & - \\
\hline & & & & & & & & & 19 & - & 1 & 16 & 63 & 1 \\
\hline & & & & & & & & & 49 & - & - & 9 & 42 & 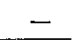 \\
\hline & & & & & & & & & \multicolumn{6}{|c|}{ Only 35 grains non-opaque } \\
\hline
\end{tabular}

1) See pag. 203.

4) For the detailed results of the mineral countings see Tables 18 to 21 . 
Table 2. Physical and Chemical Composition.

\begin{tabular}{|c|c|c|c|c|c|c|c|c|c|}
\hline \multirow{2}{*}{ 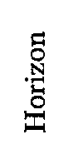 } & \multicolumn{3}{|c|}{$\begin{array}{l}\text { Mechanical } \\
\text { composition }\end{array}$} & \multirow{2}{*}{$\mathrm{pH}$} & \multirow{2}{*}{$\begin{array}{c}\% \\
\text { Org- } \\
\text { anic } \\
\mathbf{C}\end{array}$} & \multicolumn{4}{|c|}{ Composition of clay fraction } \\
\hline & $\underset{\%}{44} \mu$ & $\underset{\%}{44-2} \mu$ & $<\underset{\%}{2} \mu$ & & & $\mathrm{SiO}_{2} / \mathrm{R}_{2} \mathrm{O}_{3}$ & $\mathrm{SiO}_{2} / \mathrm{Al}_{2} \mathrm{O}_{3}$ & $\mathrm{SiO}_{2} / \mathrm{Fe}_{2} \mathrm{O}_{3}$ & $\mathrm{Al}_{2} \mathrm{O}_{3} / \mathrm{Fe}_{2} \mathrm{O}_{3}$ \\
\hline $\begin{array}{l}\mathrm{A}_{1} \\
\mathrm{~A}_{2} \\
\mathrm{~B} \\
\mathrm{C}_{1} \\
\mathrm{C}_{2}\end{array}$ & $\begin{array}{l}32.6 \\
32.6 \\
33.5 \\
62.3 \\
74.0\end{array}$ & $\begin{array}{l}27.7 \\
33.8 \\
36.9 \\
27.8 \\
17.3\end{array}$ & $\begin{array}{r}24.9 \\
28.8 \\
30.9 \\
11.9 \\
9.3\end{array}$ & $\begin{array}{l}4.98 \\
4.96 \\
4.82 \\
5.04 \\
4.42\end{array}$ & $\begin{array}{l}8.7 \\
3.5 \\
0.9 \\
0.3 \\
0.2\end{array}$ & $\begin{array}{l}1.64 \\
1.54 \\
1.43 \\
1.58 \\
1.81\end{array}$ & $\begin{array}{l}1.79 \\
1.68 \\
1.58 \\
1.72 \\
1.88\end{array}$ & $\begin{array}{l}18.6 \\
19.5 \\
17.1 \\
20.1 \\
49.6\end{array}$ & $\begin{array}{l}10.4 \\
11.6 \\
10.8 \\
11.7 \\
26.4\end{array}$ \\
\hline & & & & & & & & & \\
\hline
\end{tabular}

Table 3. Estimated Composition of the Clay Fraction.

\begin{tabular}{|c|c|c|c|c|c|}
\hline Horizon & 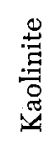 & $\frac{\stackrel{0}{0}}{0.0}$ & $\frac{\frac{1}{\pi}}{\overbrace{0}^{0}}$ & 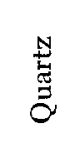 & 䒿 \\
\hline 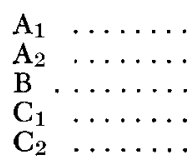 & $\begin{array}{l}55 \\
52 \\
64 \\
66 \\
67\end{array}$ & $\begin{array}{r}\overline{15} \\
18 \\
16 \\
<1\end{array}$ & $\begin{array}{r}45 \\
25 \\
14 \\
13 \\
7\end{array}$ & $\begin{array}{r}<\overline{1} \\
4 \\
5 \\
20\end{array}$ & $\begin{array}{r}\overline{8} \\
<1 \\
<1 \\
6\end{array}$ \\
\hline
\end{tabular}

The conclusion to be drawn from the mineralogical analysis is that we have to do here with a liparitic tuff. The biotite, which is black in most of the tuffs from this region (Ger. "Rabenglimmer"), is frequently found to have been strongly bleached in this profile. The sanidine has admittedly been attacked, but it nevertheless occurs in fairly high percentages - a fact which indicates either a weathering process which is not yet very far advanced, or an enrichment.

The heavy mineral composition points to a faint Deli association, in view of the fact that the green amphibole percentage is too low, and the hypersthene and zircon percentages are too high, to correspond to the standard Deli association (VAN BAREN and KIEL, 1950).

Despite the fact that sanidine is rather strongly represented in the top horizons, the profile seems reasonably autochthonous; this will be further confirmed by the chemical and $\mathrm{X}$-ray analyses. The chemical analysis of the clay fraction indicates podzolic weathering. 


\section{Profile II}

Table 4.

\begin{tabular}{|c|c|c|c|c|c|c|c|c|c|c|c|c|c|}
\hline \multicolumn{8}{|c|}{$\begin{array}{l}\text { Chief minerals in the total } \\
\text { sand fraction }\end{array}$} & \multicolumn{6}{|c|}{$\begin{array}{l}\text { Composition of heavy sand } \\
\text { fraction }\end{array}$} \\
\hline \multirow{2}{*}{ 总 } & \multirow{2}{*}{ 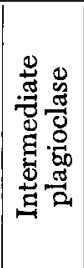 } & \multirow[b]{2}{*}{ 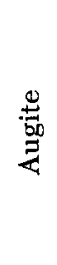 } & \multirow{2}{*}{ 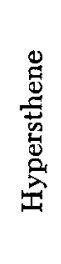 } & \multirow{2}{*}{ 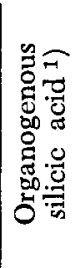 } & \multirow{2}{*}{ 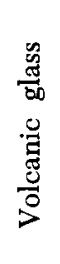 } & \multirow{2}{*}{$\begin{array}{l}\stackrel{0}{0} \\
00 \\
000 \\
000\end{array}$} & \multirow{2}{*}{ 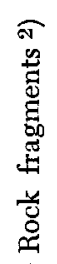 } & \multirow{2}{*}{ 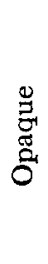 } & \multicolumn{5}{|c|}{$\begin{array}{l}\text { Content of non-opaque minerals } \\
\text { (as percentages of total content } \\
\text { of non-opaque minerals) }\end{array}$} \\
\hline & & & & & & & & & 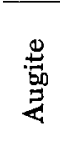 & 密: & 总 & हृ & 它 \\
\hline $\begin{array}{l}\mathrm{A}_{1} \\
\mathbf{A}_{2} \\
\mathrm{~B}_{1} \\
\mathrm{~B}_{2} \\
\mathrm{C}\end{array}$ & $\begin{array}{l}31 \\
35 \\
38 \\
47 \\
48\end{array}$ & $\begin{array}{l}1 \\
2 \\
1 \\
1 \\
-\end{array}$ & $\begin{array}{l}14 \\
14 \\
16 \\
14 \\
12\end{array}$ & $\begin{array}{l}7 \\
5 \\
9 \\
- \\
-\end{array}$ & $\begin{array}{l}14 \\
12 \\
15 \\
14 \\
12\end{array}$ & $\begin{array}{r}5 \\
7 \\
5 \\
5 \\
13\end{array}$ & $\begin{array}{r}9 \\
10 \\
5 \\
4 \\
7\end{array}$ & $\begin{array}{l}43 \\
21 \\
30 \\
21 \\
39\end{array}$ & $\begin{array}{r}10 \\
7 \\
7 \\
1 \\
3\end{array}$ & $\begin{array}{l}82 \\
85 \\
91 \\
95 \\
96\end{array}$ & $\begin{array}{l}\text { tr. } \\
- \\
- \\
\text { tr. }\end{array}$ & $\begin{array}{l}5 \\
5 \\
2 \\
3 \\
1\end{array}$ & $\begin{array}{l}3 \\
3 \\
-1 \\
-\end{array}$ \\
\hline
\end{tabular}

1) See pag. 203.

2) The rock fragments are largely bordered with gibbsite.

Table 5. Physical and Chemical Composition.

\begin{tabular}{|c|c|c|c|c|c|c|c|c|c|}
\hline \multirow{2}{*}{$\begin{array}{l}\text { 온 } \\
\text { 온 }\end{array}$} & \multicolumn{3}{|c|}{$\begin{array}{l}\text { Mechanical } \\
\text { composition }\end{array}$} & \multirow{2}{*}{$\mathrm{pH}$} & \multirow{2}{*}{$\begin{array}{c}\% \\
\text { Org- } \\
\text { anic } \\
\mathrm{C}\end{array}$} & \multicolumn{4}{|c|}{ Composition of clay fraction } \\
\hline & $>\underset{\%}{44} \mu$ & $\underset{\%}{44-2} \mu$ & $<\underset{\%}{2} \mu$ & & & $\mathrm{SiO}_{2} / \mathrm{R}_{2} \mathrm{O}_{3}$ & $\mathrm{SiO}_{2} / \mathrm{Al}_{2} \mathrm{O}_{3}$ & $\mathrm{SiO}_{2} / \mathrm{Fe}_{2} \mathrm{O}_{3}$ & $\mathrm{Al}_{2} \mathrm{O}_{3} / \mathrm{Fe}_{2} \mathrm{O}_{3}$ \\
\hline $\begin{array}{l}\mathbf{A}_{1} \\
\mathbf{A}_{2} \\
\mathbf{B}_{1} \\
\mathbf{B}_{2} \\
\mathbf{C}\end{array}$ & $\begin{array}{l}23.0 \\
24.4 \\
25.6 \\
34.7 \\
62.0\end{array}$ & $\begin{array}{l}30.3 \\
37.2 \\
37.0 \\
34.3 \\
25.8\end{array}$ & $\begin{array}{l}11.7 \\
12.0 \\
16.9 \\
21.2 \\
12.7\end{array}$ & $\begin{array}{l}4.80 \\
5.26 \\
5.48 \\
5.80 \\
6.24\end{array}$ & $\begin{array}{r}16.6 \\
10.1 \\
5.4 \\
2.0 \\
0.7\end{array}$ & $\begin{array}{l}1.48 \\
0.76 \\
0.68 \\
0.72 \\
0.80\end{array}$ & $\begin{array}{l}1.78 \\
0.88 \\
0.77 \\
0.81 \\
0.87\end{array}$ & $\begin{array}{c}8.42 \\
5.10 \\
5.73 \\
6.60 \\
10.0\end{array}$ & $\begin{array}{r}4.75 \\
5.85 \\
7.47 \\
8.26 \\
11.50\end{array}$ \\
\hline
\end{tabular}

Table 6. Estimated Composition of the Clay Fraction.

\begin{tabular}{|c|c|c|c|c|c|}
\hline Horizon & 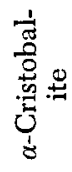 & $\begin{array}{l}\stackrel{0}{0} \\
\frac{10}{0} \\
\text { 00 }\end{array}$ & 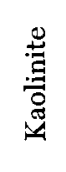 & 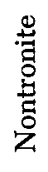 & 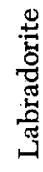 \\
\hline 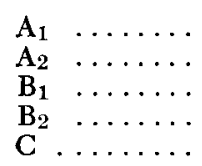 & $\begin{array}{l}10 \\
20 \\
15 \\
10 \\
<1\end{array}$ & $\begin{array}{l}25 \\
30 \\
45 \\
55 \\
35\end{array}$ & $\begin{array}{r}25 \\
10 \\
5 \\
5 \\
<1\end{array}$ & $\begin{array}{l}30 \\
20 \\
15 \\
15 \\
25\end{array}$ & $\begin{array}{l}10 \\
20 \\
20 \\
15 \\
40\end{array}$ \\
\hline
\end{tabular}


This profile is more or less an example of an autochthonous profile formed from andesitic tuff with a hypersthene association. The physical analysis reveals a clay enrichment in the $\mathrm{B}$ horizon. The granular analysis also points to the profile's possessing a pronounced autochthonous character. The weathering is podzolic, as regards both the enrichment of clay and the course of its chemical composition.

One remarkable feature is the occurrence of nontronite in the clay - a fact which has already been reported by FaUst and Callaghan (1948). They found that this mineral can be formed by weathering of volcanic glass and hypersthene in glassy crystalline tuffs.

\section{Profile III}

Table 7.

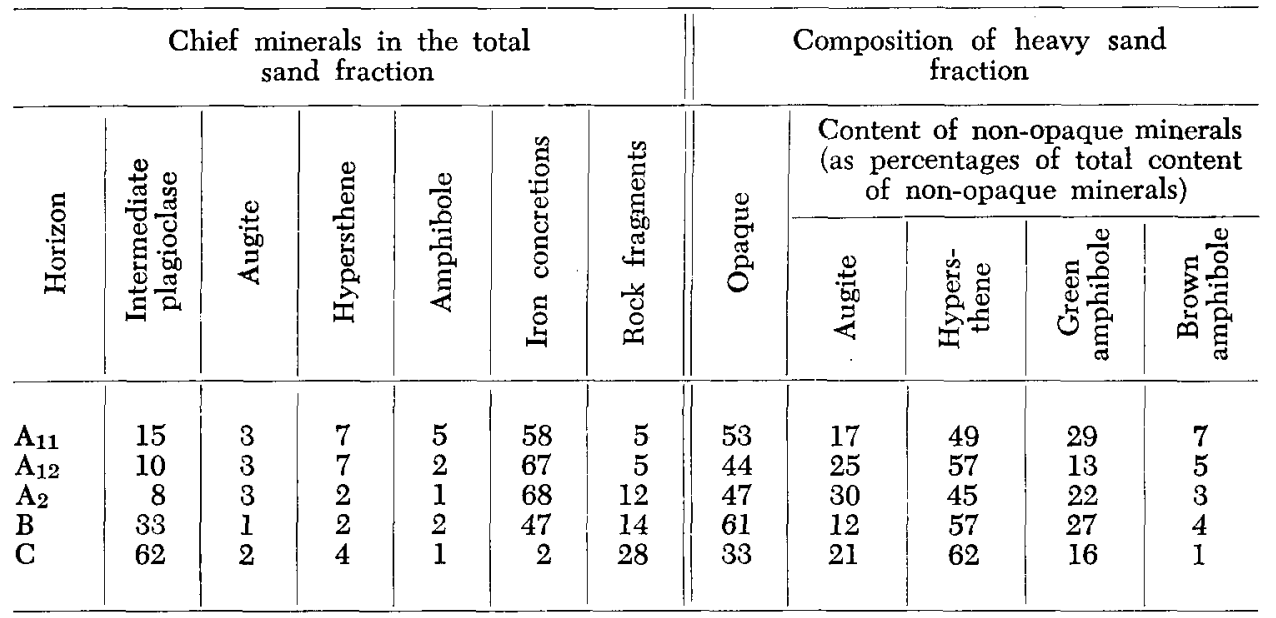

Table 8. Physical and Chemical Composition.

\begin{tabular}{|c|c|c|c|c|c|c|c|c|c|}
\hline \multirow{2}{*}{ 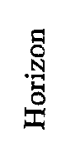 } & \multicolumn{3}{|c|}{$\begin{array}{l}\text { Mechanical } \\
\text { composition }\end{array}$} & \multirow{2}{*}{$\mathrm{pH}$} & \multirow{2}{*}{$\begin{array}{c}\% \\
\text { Org- } \\
\text { anic } \\
C\end{array}$} & \multicolumn{4}{|c|}{ Composition of clay fraction } \\
\hline & $>\underset{\%}{>44} \mu$ & $\underset{\%}{44-2} \mu$ & $<\underset{\%}{2} \mu$. & & & $\mathrm{SiO}_{2} / \mathrm{R}_{2} \mathrm{O}_{3}$ & $\mathrm{SiO}_{2} / \mathrm{Al}_{2} \mathrm{O}_{3}$ & $\mathrm{SiO}_{2} / \mathrm{Fe}_{2} \mathrm{O}_{3}$ & $\mathrm{Al}_{2} \mathrm{O}_{3} / \mathrm{Fe}_{2} \mathrm{O}_{3}$ \\
\hline $\begin{array}{l}\mathbf{A}_{11} \\
\mathbf{A}_{12} \\
\mathbf{A}_{2} \\
\mathrm{~B} \\
\mathrm{C}\end{array}$ & $\begin{array}{l}27.1 \\
33.9 \\
48.5 \\
42.1 \\
59.5\end{array}$ & $\begin{array}{l}41.4 \\
53.2 \\
34.4 \\
44.0 \\
23.9\end{array}$ & $\begin{array}{l}25.9 \\
23.9 \\
14.2 \\
15.5 \\
19.8\end{array}$ & $\begin{array}{l}5.92 \\
5.86 \\
5.70 \\
5.65 \\
5.93\end{array}$ & $\begin{array}{l}0.9 \\
0.8 \\
0.7 \\
0.7 \\
0.3\end{array}$ & $\begin{array}{c}2.06 \\
1.97 \\
\text { not known } \\
2.02 \\
1.90\end{array}$ & $\begin{array}{c}2.32 \\
2.21 \\
\text { not known } \\
2.23 \\
2.03\end{array}$ & $\begin{array}{c}17.9 \\
17.9 \\
\text { not known } \\
22.0 \\
29.0\end{array}$ & $\begin{array}{r}7.72 \\
8.10 \\
8.70 \\
9.85 \\
14.3\end{array}$ \\
\hline
\end{tabular}

Table 9. Estimated Composition of the Clay Fraction.

\begin{tabular}{|c|c|c|}
\hline Horizon & Halloysite-2 & $\alpha$-Cristobalite \\
\hline 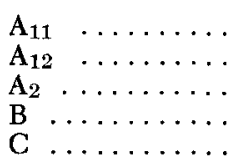 & $\begin{array}{l}95 \\
90 \\
90 \\
90 \\
60\end{array}$ & $\begin{array}{r}5 \\
10 \\
10 \\
10 \\
40\end{array}$ \\
\hline
\end{tabular}


Circumstances rendered it necessary to analyze the samples from this profile after they had been dried at the air. For this reason, the results of the mineral count of the sand fraction and the silt analysis are not to be relied upon. For drying, in the case of mountain soils, manifests itself in what is called "mountain granulation", by which is meant the cementing-together of the silt and clay particles to form highly stable aggregates. Hence, the number of iron concretions is very large. In addition, the sand content must be smaller and the clay content larger than is shown by the analysis.

Experiments have proved that the clay fraction isolated from air-dried samples possesses the same composition as the clay isolated from field-wet samples. The results of the chemical analysis of the clay are therefore reliable.

In the nature of the case, the analysis of the heavy sand fraction is also reliable.

The material is an andesitic tuff with a pyroxene - amphibole association. The lowest horizon may possibly consist of a rather different material; this view is supported by the chemical analysis.

One striking point is the content of organic matter, which is very low for these types of soil. This is due to the soil having previously been under cultivation. Consequently, no further supply of organic material took place, and no root development, and therefore, owing to the rapid combustion of the organic matter, the content declined quickly and very markedly.

In spite of deforestation, no erosion phenomena are noticeable, and this profile can consequently be used for purposes of genetic and classification research (see pp. 203 and 208).

\section{Profile IV}

Table 10.

\begin{tabular}{|c|c|c|c|c|c|c|c|c|c|c|c|c|}
\hline \multicolumn{7}{|c|}{$\begin{array}{l}\text { Chief minerals in the total } \\
\text { sand fraction }\end{array}$} & \multicolumn{6}{|c|}{$\begin{array}{l}\text { Composition of heavy sand } \\
\text { fraction }\end{array}$} \\
\hline \multirow{2}{*}{ : } & \multirow{2}{*}{ 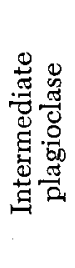 } & \multirow{2}{*}{ 总 } & \multirow{2}{*}{ 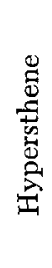 } & \multirow{2}{*}{ 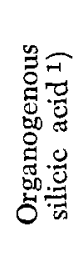 } & \multirow{2}{*}{ 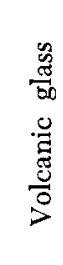 } & \multirow{2}{*}{ 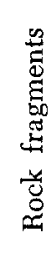 } & \multirow{2}{*}{ 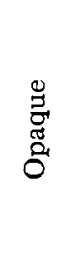 } & \multicolumn{5}{|c|}{$\begin{array}{l}\text { Content of non-opaque minerals } \\
\text { (as percentages of total content } \\
\text { of non-opaque minerals) }\end{array}$} \\
\hline & & & & & & & & 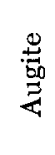 & 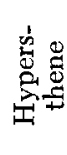 & 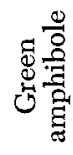 & 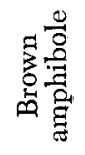 & 尝 \\
\hline & & & & & & & & & & & & \\
\hline 11 & & 0 & I & 3 & 1 & & 41 & 2 & 00 & 5 & race & $\overrightarrow{-}$ \\
\hline & 35 & $\begin{array}{l}3 \\
5\end{array}$ & $\begin{array}{l}5 \\
9\end{array}$ & 2 & 20 & 2 & 4 & 3 & 64 & 3 & trace & 2 \\
\hline $\mathbf{A}^{\prime}$ & 24 & 6 & 5 & I & 12 & 3 & 12 & 32 & 59 & 4 & 1 & 4 \\
\hline $\mathrm{A}^{\prime}{ }_{12}$ & 23 & 8 & 7 & tr. & 9 & 29 & 37 & 20 & 72 & 6 & - & 2 \\
\hline
\end{tabular}

1) See p. ...

Table 11. Physical and Chemical Composition.

\begin{tabular}{|c|c|c|c|c|c|c|c|c|c|}
\hline \multirow{2}{*}{$\begin{array}{l}\text { 总 } \\
\text { 蛋 }\end{array}$} & \multicolumn{3}{|c|}{$\begin{array}{l}\text { Mechanical } \\
\text { composition }\end{array}$} & \multirow{2}{*}{$\mathrm{pH}$} & \multirow{2}{*}{$\begin{array}{c}\% \\
\text { Org- } \\
\text { anic } \\
C\end{array}$} & \multicolumn{4}{|c|}{ Composition of clay fraction } \\
\hline & $\underset{\%}{>44} \mu$ & $\underset{\%}{44-2} \mu$ & $<{ }_{\%}^{2} \mu$ & & & $\mathrm{SiO}_{2} / \mathrm{R}_{2} \mathrm{O}_{3}$ & $\mathrm{SiO}_{2} / \mathrm{Al}_{2} \mathrm{O}_{3}$ & $\mathrm{SiO}_{2} / \mathrm{Fe}_{2} \mathrm{O}_{3}$ & $\mathrm{Al}_{2} \mathrm{O}_{3} / \mathrm{Fe}_{2} \mathrm{O}_{3}$ \\
\hline $\begin{array}{l}A_{11} \\
A_{12} \\
B \\
A^{\prime}{ }_{11} \\
A^{\prime}{ }_{12}\end{array}$ & $\begin{array}{l}28.3 \\
34.7 \\
38.3 \\
26.3 \\
29.1\end{array}$ & $\begin{array}{l}39.0 \\
40.1 \\
50.1 \\
52.8 \\
53.3\end{array}$ & $\begin{array}{r}11.3 \\
9.8 \\
8.3 \\
10.2 \\
9.7\end{array}$ & $\begin{array}{l}5.69 \\
5.74 \\
5.77 \\
5.81 \\
5.93\end{array}$ & $\begin{array}{r}10.0 \\
7.5 \\
2.8 \\
4.3 \\
2.8\end{array}$ & $\begin{array}{l}2.18 \\
1.30 \\
1.17 \\
1.15 \\
0.97\end{array}$ & $\begin{array}{l}2.87 \\
1.53 \\
1.36 \\
1.44 \\
1.16\end{array}$ & $\begin{array}{l}9.06 \\
8.42 \\
8.46 \\
5.67 \\
6.06\end{array}$ & $\begin{array}{l}3.16 \\
5.50 \\
6.20 \\
4.00 \\
5.25\end{array}$ \\
\hline
\end{tabular}


Table 12. Estimated Composition of the Clay Fraction.

\begin{tabular}{c|c|c|c|c|c}
\hline Horizon & Halloysite-2 & $\begin{array}{c}\text { Montmoril- } \\
\text { lonite }\end{array}$ & $\begin{array}{c}\alpha \text {-Cristo- } \\
\text { balite }\end{array}$ & Mica & $\begin{array}{c}\text { Labra- } \\
\text { dorite }\end{array}$ \\
\hline $\mathrm{A}_{11} \ldots \ldots \ldots$ & 40 & 20 & 10 & 20 & 10 \\
$\mathrm{~A}_{12} \ldots \ldots \ldots$ & 15 & 30 & 15 & 30 & 10 \\
$\mathrm{~B}^{\prime} \ldots \ldots \ldots$ & 10 & 30 & 20 & 30 & 15 \\
$\mathrm{~A}^{\prime} \mathrm{A}^{\prime} \ldots \ldots \ldots$ & 80 & $\overline{25}$ & $\overline{10}$ & $\overline{25}$ & 20 \\
\hline
\end{tabular}

Although the material is of the same composition throughout the entire profile (see heavy fraction), this profile, in the opinion of the writers, is a covered profile. The lowest horizon but one possesses a greater content of organic matter than the horizons lying above it, and the content of organic matter of the lowest horizon is likewise much too high to qualify it to be regarded as parent material. Here it is almost certain that we are concerned with two deposits, originating from two eruptions, between which a considerable period of time elapsed, thus rendering possible development of a vegetation. This is the reason for the disparate designation of the horizons in the profile.

Nevertheless, the profile can be used for genetic observations, provided the above is kept constantly in mind.

The material is basalto-andesitic tuff with a hypersthene-augite association.

Finally, a few remarks concerning the results mentioned above.

1 The mineral counts give an average picture of the sand fraction; this was obtained by averaging arithmetically the counts of the various fractions - a method which is not entirely accurate, but was sufficiently so for our purpose. For details of the analysis reference should be made to Tables 18-21.

2 The estimate of the mineral composition of the clay fraction prompts the assumption that only the minerals named occur in this fraction. This assumption is correct as regards the profiles from Tapanuli, but it is anything but correct as regards those from Java, The X-ray diffraction photographs of the samples from Java exhibit pronounced diffusion of the $\mathrm{X}$-ray radiation, which points to the presence of much amorphous material. For that reason the fluctuations in the percentages stated are, in actual fact, considerably smaller. The amorphous material may consist of volcanic glass and silicic acid, which also occurs in the sand fraction, and about which more will be said later.

3 In the tables relating to the composition of the sand fraction, particles will be found included under the name of "organogenous silicic acid". These particles are found especially under vegetation, i.e. tropical rain forest (Tjianten). The particles are often in the shape of little tubes or spheres, and are isotropic. Opinions differ as to their origin. VAN RUMMELEN (1953) presumes that they are due to precipitation of silicic acid round root hairs, while others (verbal communication from Professor B. PoLAK) hold the view that they are skeletons of certain lower vegetable organisms. Whatever the truth on that point may be, these particles occur most commonly in those horizons which must be intensely vital, i.e. which are rich in organic matter and contain many roots.

\section{The CLASSIFICATION OF THE SOILS EXAMINED}

The profile descriptions show that the soils examined can be divided into three groups, viz. :
A. profile I from Tapanuli ;
B. profiles II and III from West and East Java;
C. profile IV from East Java. 
A. The Tapanuli profile is characterized by dark grey/black to dark reddishbrown/dark brown A horizons, lying on reddish-yellow to dark yellowish-brown $\mathrm{B}$ horizons, while the $\mathrm{C}$ horizons vary in colour from white/pale brown to yellow/brownish-yellow. There is no indication of bleaching of the $A_{2}$ zone. The $\mathrm{pH}$ indexes do not greatly vary, and are fairly low. The content of organic matter decreases strongly within the A horizon, and thereafter gradually towards the $\mathrm{C}$ horizon. The texture does not differ to any great extent within the same parent material. The composition of the clay indicates that a podzolic soil formation is concerned here.

In the U.S.A. the same characteristics are found in soils formed from acid rocks under humid, temperate climatic conditions. Such soils are classified as "brown podzolic soils" (BALDwIN, 1938; LYFoRd, 1947, 1952; ClINE, 1949; Nygard et al., 1952; Swanson et al., 1952 ; Tsuneo Tamura and Swanson, 1954).

Nikiforoff (1937) assigns these soils to the "cryptopodzolic" soils, because the - slight enough - bleaching in the A horizon is overshadowed by the content of organic matter. This is also the case in the soils examined by us, as can be seen from the variation in colour of the oxidized soil, and in particular that of the clay fraction: $\mathrm{A}_{1}$, pale brown (10YR6/3); $\mathrm{A}_{2}$, yellow (10YR7/6); $\mathrm{B}$, reddish yellow $(7.5 \mathrm{YR} 7 / 6) ; \mathrm{C}_{1}$, yellow $(10 \mathrm{YR} 8 / 6) ; \mathrm{C}_{2}$, yellow $(7.5 \mathrm{YR} 8 / 6)$. The course of the chemical composition of the clay fraction likewise shows a close resemblance to an analysis of a brown podzolic soil developed on porphyritic rhyolite (RoBinson, 1949, p. 318), and of a soil developed on "unstratified glacial drift" (a mixture of equal quantities of red sandstone, diorite and basalt, Tsuneo and Swanson, 1954). For the sake of completeness the data of the last-mentioned authors, converted to molar ratios, are given in Table 13.

Table 13. Composition of the Clay of a Brown Podzolic Soil from Connecticut.

\begin{tabular}{|c|c|c|c|c|c|c|c|c|}
\hline & \multicolumn{4}{|c|}{ Fraction $2-0.2 \mu$} & \multicolumn{4}{|c|}{ Fraction $<0.2 \mu$} \\
\hline & $\frac{\mathrm{SiO}_{2}}{\mathrm{R}_{2} \mathrm{O}_{3}}$ & $\frac{\mathrm{SiO}_{2}}{\mathrm{Al}_{2} \mathrm{O}_{3}}$ & $\frac{\mathrm{SiO}_{2}}{\mathrm{Fe}_{2} \mathrm{O}_{3}}$ & $\frac{\mathrm{Al}_{2} \mathrm{O}_{3}}{\mathrm{Fe}_{2} \mathrm{O}_{3}}$ & $\frac{\mathrm{SiO}_{2}}{\mathrm{R}_{2} \mathrm{O}_{3}}$ & $\frac{\mathrm{SiO}_{2}}{\mathrm{Al}_{2} \mathrm{O}_{3}}$ & $\frac{\mathrm{SiO}_{2}}{\mathrm{Fe}_{2} \mathrm{O}_{3}}$ & $\frac{\mathrm{Al}_{2} \mathrm{O}_{3}}{\mathrm{Fe}_{2} \mathrm{O}_{3}}$ \\
\hline $\begin{array}{l}\mathrm{A}_{1} \ldots \ldots \\
\mathbf{B}_{1} / \mathrm{B}_{2} \ldots \ldots \\
\mathbf{B}_{3} \ldots \ldots \\
\mathrm{C}_{1} / \mathrm{C}_{2} \ldots \ldots \\
\mathrm{C}_{3} \ldots \ldots\end{array}$ & $\begin{array}{l}2.86 \\
2.32 \\
2.31 \\
2.51 \\
2.75\end{array}$ & $\begin{array}{l}3.51 \\
3.08 \\
3.06 \\
3.39 \\
3.52\end{array}$ & $\begin{array}{c}15.4 \\
9.40 \\
9.40 \\
9.79 \\
12.7\end{array}$ & $\begin{array}{l}4.40 \\
4.00 \\
3.08 \\
2.89 \\
3.60\end{array}$ & $\begin{array}{l}2.44 \\
2.13 \\
2.24 \\
2.62 \\
2.63\end{array}$ & $\begin{array}{l}3.16 \\
2.87 \\
2.95 \\
3.47 \\
3.44\end{array}$ & $\begin{array}{c}10.7 \\
8.21 \\
9.25 \\
9.46 \\
11.1\end{array}$ & $\begin{array}{l}3.39 \\
2.87 \\
3.14 \\
2.60 \\
3.21\end{array}$ \\
\hline
\end{tabular}

It is clear that, if the total clay content had been analyzed, a picture would have been obtained which corresponds entirely with the results of our analysis, in the case in which the fraction $<0.2 \mu$ was most strongly represented.

From the above, the present writers consider themselves justified in concluding that the soils of Tapanuli can be classified as brown podzolic soils. There is, however, a slight possibility that the soils in question may constitute a weak transition to the red-yellow podzolic soils described by Simonson (1949) and LyFond (1952). According to these two authors the red-yellow podzolic soils in America are formed in humid, temperate to warm climates (although they may also occur in tropical climates), on parent rocks rich in quartz - in other words, under the same conditions as are present in Tapanuli 
at an altitude of $1000-1500 \mathrm{~m}$. The vegetation is also the same in both cases. In the red-yellow podzolic soils, however, a light-coloured, bleached $\mathrm{A}_{2}$ horizon occurs, in respect of which only a faint indication, in the colour of the clay fraction, is found in the Tapanuli profiles.

The other profiles, six in number, which were excluded from genetic consideration for the reasons given on p. 194, and which occurred at altitudes varying from 1000 to $1500 \mathrm{~m}$, exhibited the same characteristics, and consequently the above conclusion appears to be justified.

B. Profiles II and III can be characterized as follows :

the $A_{1}$ horizons vary from dark greyish-brown/black to black;

the $\mathrm{A}_{2}$ horizons vary from pale brown/dark brown to dark brown/very dark greyish-brown ;

the B horizons vary from light yellowish-brown/bright brown to dark yellowish-red brown/dark brown;

the $\mathrm{C}$ horizons vary from yellow/brownish-yellow to brownish-yellow/dark brownish-yellow.

Profile III differs from the above because, owing to deforestation and cultivation of the land, the content of organic matter in the soil concerned has considerably decreased (further reference is made to this on p. 211).

The $\mathrm{pH}$ indexes are substantially higher than in the brown podzolic soils of Tapanuli, and increase regularly in a downwards direction in the profile. They vary from between 4.6 and 5.2 in the $\mathrm{A}_{1}$ horizon to between 5.2 and 6.2 in the $\mathrm{C}$ horizons. The trend of the organic matter content is the same as in the Tapanuli profiles; it decreases strongly within the A horizon, and thereafter gradually to the $\mathrm{C}$ horizon. The soils belong to the loam soils, and there is an enrichment of clay in the B horizon ranging from fairly distinct to very distinct.

The thicker the $\mathrm{A}_{2}$ horizon, the lower the $\mathrm{pH}$. No bleaching can be observed in the profiles, which still originate from under natural vegetation, because the content of organic matter entirely conceals this phenomenon. It is, however, definitely present, as is demonstrated by Profile III, in which the content of organic matter has substantially decreased. After oxidation with hydrogen peroxide to destroy the organic matter, it can be observed, as a general rule, that a bleached layer is also present in the other profile. This can be seen from the variation in colour of the clay fraction of Profile II after oxidation : $\mathrm{A}_{1}$, light greyish-brown (10YR6/2); $\mathrm{A}_{2}$, pale brown (10YR6/3); $\mathrm{B}_{1}$, light yellowish-brown (10YR6/4); $\mathrm{B}_{2}$, reddish-yellow (7.5YR6/6); $\mathrm{C}$, yellow (10YR8/6).

Accordingly, it would be possible to follow NikiforofF (1937) in assigning these soils to the cryptopodzolic soils. This name, however, does not tittingly characterize them, since the brown podzolic soils also fall within that group. As, however, the profile characteristics described entirely correspond with those of the grey-brown podzolic soils of America, the present writers consider themselves justified in classifying the soils formed from andesitic tuff at altitudes varying from 1000 to $1500 \mathrm{~m}$ as grey-brown podzolic soils. (For characterization of the American grey-brown podzolic soils reference should be made to Baldwin, 1927; Lyford, 1947, 1952; Cline, 1949 ; McCaleb and Cline, 1950 ; Bidwell and Page, 1951; Stobbe, 1952 ; and Gardner and Whiteside, 1952). 
At first sight, rather serious objections might be raised to the above conclusion, the more so as JENNY (1948) classifies similar soils in equatorial Colombia as "humic yellow-brown" soils.

LEFAURIE-ACOSTA, on the other hand (quoted by JENNY, 1948) again assigns the - admittedly rather higher situated - soils to the "grey-brown podzolic" soils.

The possible objections may be of two kinds. In the first place, the most typical profiles in America, occurring in the states of New York (Curne, 1949) and Michigan (GARDNER and Whiteside, 1952), are formed on calcareous parent material consisting of mixtures of acid and basic minerals (glacial drift). This is also the case in eastern Canada (Sтовве, 1952). However, less typical "greybrown podzolic" soils also occur in America south of the Wisconsin terminal moraine on all kinds of other parent materials, provided they do not possess too coarse a texture or too much quartz. Brown podzolic soils are then formed on the coarse parent materials which contain an abundance of quartz. In Indonesia the parent material is not calcareous; but quartz is absent. Here, too, brown podzolic soils are formed, if a great deal of quartz is present (Tapanuli).

In the second place, the climates are different. In America the grey-brown podzolic soils occur in the humid temperate climatic zones (CurNe, 1949), which are roughly characterized by an average annual temperature of $7-10^{\circ} \mathrm{C}$ (average summer temperature, $21^{\circ} \mathrm{C}$; average winter temperature, $-4^{\circ} \mathrm{C}$ to $\left.-1^{\circ} \mathrm{C}\right)$; an average, evenly distributed precipitation of 750 to $1150 \mathrm{~mm}$ per year; a snowfall of 500 to $750 \mathrm{~mm}$ per year, and a relative humidity of the air of 70-90\% (BALDWIN, 1927). In Indonesia the average annual temperature is $20-10^{\circ} \mathrm{C}$, in which no seasonal fluctuations occur; the average annual precipitation varies from 5400 to $2200 \mathrm{~mm}$, which is evenly distributed in West Java and reaches a minimum in July, August and September in East Java; and the relative humidity of the air in the natural vegetation approaches $100 \%$.

One point of correspondence is, however, afforded by the vegetation, in so far that in neither case did the original vegetation contain conifers. In America a vegetation of hard wood is found in the regions of typical grey-brown podzolic soils, and in Indonesia rain forest.

Yet another difference relates to the mineralogical composition of the clay fraction. The grey-brown podzolic soils of America are chiefly composed of illite, with admixtures of vermiculite and montmorillonite in the more alkaline profiles, and of kaolinite in the more acid profiles (McCaleb, 1954; Simonson, 1949; BwwEll and PAGE, 1951). In Indonesia, on the other hand, the clay fraction contains : $\alpha$-cristobalite, halloysite- 2 , gibbsite, montmorillonite and kaolinite, and an abundance of amorphous material (volcanic glass).

In spite of these dissimilarities, the points of correspondence between the profile characteristics are so close that the present writers adhere to their conclusion that the mountain soils, formed on andesitic tuff and under humid conditions, may be allocated to the grey-brown podzolic soils; in view of the difference in clay minerals, the qualification "tropical" might be assigned to them. Further consideration will be given to this in the course of the observations regarding the genesis of these soils.

C. Profile IV exhibits some characteristics which differ from those of the 
profiles just discussed. The differences consist chiefly in colour, clay content and $\mathrm{pH}$. In colour, Profile IV is considerably darker, being much browner, especially as regards the deeper horizons. Within a solum the clay content decreases in a downward direction; no mechanical illuviation is therefore observable. The $\mathrm{pH}$ is almost constant throughout the entire profile, and very definitely so within a solum. Bleaching of a specific horizon is entirely absent, as can be seen, inter alia, from the colour variation after oxidation of the organic matter: $A_{11}$, very pale brown (10YR7/3); $A_{12}$, very pale brown $(10 \mathrm{YR} 7 / 4) ; \mathrm{B}$, yellow (10YR8/6-7/6); $\mathrm{A}_{11}^{\prime}$, yellow (10YR8/6-7/6); $\mathrm{A}^{\prime}{ }_{12}$, brownish-yellow (10YR5/6). The parent material is rather more basic, viz. basalto-andesitic. Moreover, the chemical composition of the clay is also different, although points of agreement also occur (see Table 14).

Table 14. Composition of the Clay Fraction of Profiles II and IV.

\begin{tabular}{|c|c|c|c|c|c|c|c|c|c|c|}
\hline & \multicolumn{5}{|c|}{$\begin{array}{l}\text { "Grey-brown podzolic soil" } \\
\text { (Profile II) }\end{array}$} & \multicolumn{5}{|c|}{ Profile IV } \\
\hline & $\mathbf{A}_{1}$ & $\mathrm{~A}_{2}$ & $\mathrm{~B}_{1}$ & $\mathrm{~B}_{2}$ & $\mathrm{C}$ & $\mathbf{A}_{11}$ & $\mathrm{~A}_{12}$ & B & $\mathrm{A}^{\prime}{ }_{11}$ & $\mathbf{A}^{\prime}{ }_{12}$ \\
\hline $\begin{array}{llll}\% & \mathrm{SiO}_{2} & \ldots \\
\% & \mathrm{Al}_{2} \mathrm{O}_{3} & \ldots \\
\% & \mathrm{Fe}_{2} \mathrm{O}_{3} & \ldots\end{array}$ & $\begin{array}{r}26.4 \\
26.2 \\
8.4\end{array}$ & $\begin{array}{r}18.5 \\
36.1 \\
9.6\end{array}$ & $\begin{array}{r}19.4 \\
43.1 \\
9.1\end{array}$ & $\begin{array}{r}19.5 \\
41.2 \\
7.8\end{array}$ & $\begin{array}{r}21.6 \\
42.2 \\
5.8\end{array}$ & $\begin{array}{l}37.5 \\
22.2 \\
11.0\end{array}$ & $\begin{array}{r}29.8 \\
33.0 \\
9.5\end{array}$ & $\begin{array}{r}26.9 \\
33.5 \\
8.5\end{array}$ & $\begin{array}{l}24.2 \\
28.7 \\
11.4\end{array}$ & $\begin{array}{l}22.9 \\
33.8 \\
10.1\end{array}$ \\
\hline $\begin{array}{l}\mathrm{SiO}_{2} / \mathrm{R}_{2} \mathrm{O}_{3} \\
\mathrm{SiO}_{2} / \mathrm{Al}_{2} \mathrm{O}_{3}\end{array} \ldots \ldots$ & $\begin{array}{l}1.48 \\
1.78 \\
8.42 \\
4.75\end{array}$ & $\begin{array}{l}0.76 \\
0.88 \\
5.10 \\
5.85\end{array}$ & $\begin{array}{l}0.68 \\
0.77 \\
5.73 \\
7.47\end{array}$ & $\begin{array}{l}0.72 \\
0.81 \\
6.60 \\
8.26\end{array}$ & $\begin{array}{l}0.80 \\
0.87 \\
10.0 \\
11.5\end{array}$ & $\begin{array}{l}2.18 \\
2.87 \\
9.06 \\
3.16\end{array}$ & $\begin{array}{l}1.30 \\
1.53 \\
8.42 \\
5.50\end{array}$ & $\begin{array}{l}1.17 \\
1.36 \\
8.46 \\
6.20\end{array}$ & $\begin{array}{l}1.15 \\
1.44 \\
5.67 \\
4.00\end{array}$ & $\begin{array}{l}0.97 \\
1.16 \\
6.06 \\
5.25\end{array}$ \\
\hline
\end{tabular}

In the case of Profile II the $\mathrm{SiO}_{2}$ content first decreases, then gradually increases, while in Profile IV a constant decrease is observed, at any rate within a solum. In Profile II the $\mathrm{Fe}_{2} \mathrm{O}_{3}$ decreases gradually, after an initial increase $\left(\mathrm{A}_{2}\right)$, while in Profile IV a constant decrease occurs. In both cases the $\mathrm{Al}_{2} \mathrm{O}_{3}$ content increases. A close similarity between the two profiles is also to be noted as regards the molar silicic acid-sesquioxide ratios.

It is impossible to avoid getting the impression that the soil in question here is a brown forest soil, such as was described with reference to America by Nygard et al. (1952), Cline (1949) and McCaleb and Cline (1950). A close degree of resemblance exists as regards the colour of the various horizons, the decrease in the content of clay and organic matter towards lower horizons, the $\mathrm{pH}$ values and the vegetation (absence of conifers). The parent material, on the other hand, is generally calcareous (in which case the soils are intrazonal, for instance in the state of New York : see Cline, 1949); but such soils also occur on non-calcareous materials, which, however, are then strongly basic (the most northerly parts of the states of Minnesota, Wisconsin and Michigan, round the Great Lakes : see NYGARD et al., 1952). For these reasons the present writers allocate Profile IV to the brown forest soils. Here again, the qualification "tropical" ought perhaps to be added to the name.

Summarizing, the writers come to the following conclusion. In Indonesia, at altitudes ranging from 700 to 2000 metres, under identical conditions of 
climate and vegetation, and under ideal drainage conditions, brown podzolic soils are formed on acid ejectamenta (liparitic tuff); grey-brown podzolic soils are formed on intermediary ejectamenta (andesitic tuff); and brown forest soils on intermediarily basic ejectamenta (basalto-andesitic tuff). The parent material therefore plays an essential part in formation of the soil.

It is hardly possible to classify the profiles described by Senstius (1930), because (1) the colours were not referred to a standard colour chart; (2) the mechanical analysis was carried out on air-dried samples, which is inadmissible in the case of these soils; (3) the $\mathrm{pH}$ was determined by Spurway's "Soiltex" method, which only results in a very approximate value being obtained; and (4) the chemical analyses were carried out with reference to the total quantity of soil. A comparison with the profiles described in this investigation is therefore well-nigh impossible. Nevertheless, the impression gained is that the Gunung Malabar profile, from an altitude of $2200 \mathrm{~m}$, examined by SENSTius, belongs to the brown podzolic soils. If this is correct it might be possible to arrive at the following zonal grouping as regards soils formed on andesitic parent material : from an altitude of about $700 \mathrm{~m}$ to $2000 \mathrm{~m}$, grey-brown podzolic soils are found; these are followed, from $2000 \mathrm{~m}$ upwards, by a zone of brown podzolic soils, which should finally give place to a zone of true podzols. (It is, however, doubtful whether the mountains of Java are high enough for this). The same zonation ought therefore to be found in soils formed on rather more basic parent materials, in which cases the limits of the above-mentioned zones would lie at higher altitudes. An indication to this effect is provided by the Andino-podzol (Colombia), described by JENNY (1948), which, in the opinion of the present writers, ought to be classified among the grey-brown podzolic soils; it lies at an altitude of 3600 metres and was presumably formed from diabase parent material. On the acid rocks, where the grey-brown podzolic soils are not found and the brown podzolic soils occur as low as $1000-1500 \mathrm{~m}$ above sea level, podzols must already be present at approximately $2000 \mathrm{~m}$. Proof to the effect that this actually is the case is provided by the occurrence of podzols in New Guinea in the region between the lakes of Angi Gita and Angi Giji, situated at an altitude of approximately $1900 \mathrm{~m}$. The Kubré mountain, which separates these lakes, is $2400 \mathrm{~m}$ high, and is entirely covered with podzols developed on unaltered shales, quartzites and fine quartz sandstone, i.e. acid rock (Hardon, 1936).

\section{THE GENESIS OF THE SOILS EXAMINED}

From the above, it may be concluded that the parent material on which podzolic soils are developed plays a very important part in soil formation. In the zone in which the soils occur in America, brown podzolic soils are found on acid rock (granite, gneiss, mixture of sandstone, claystone, diabase, dolerite or basalt) to weakly calcareous acid rock; grey-brown podzolic soils are found on basic, often rather strongly calcareous, parent material; and the brown forest soils on strongly basic (gabbro, basalt, diorite), usually strongly calcareous, parent material. The climates in which these soils occur are practically the same.

In Indonesia the same tendency is seen, in so far that there, too, the brown forest soils occur on the most alkaline parent material (basalto-andesitic tuff), the grey-brown podzolic soils on intermediary material (andesitic tuff), and the 208 
brown podzolic soils on acid rock (liparitic tuff). The climatic conditions are not exactly the same, but they are certainly similar, as the temperatures are the same and precipitation always exceeds evaporation. Accordingly, both in America and in Indonesia, the groups of soils mentioned might be termed "intrazonal", as one of the soil-forming factors, viz. the parent rock, sets its seal on the result of soil formation.

From the above it follows that investigation of the genesis of the podzolic soils of Indonesia must be directed towards answering the question as to why these soils were formed on less basic parent materials than in America. The explanation might be sought, in the first place, in a possible difference in the age of the soils, and in the second place in a difference in intensity of weathering.

The American podzolic soils discussed were formed after the latest ice age (Wisconsin Ice Age, equivalent to the Würm Ice Age in Europe). Accordingly, they are not more than 25.000 years old (SchUCHERT and DunBar, 1941, pp. 426, 433). The soils examined in Indonesia lie on volcanic deposits which are late Holocene to sub-Recent in age (VAN Bemmelen, 1949, Vol. IA, pp. 99, 100, 569). Their age can therefore be estimated as about 12000 years. Accordingly, the soils in Indonesia are much younger than the corresponding soils in America, and it might be further assumed that the soils examined in Indonesia do not represent final stages in a process of soil formation but are transitional forms to other soils the nature of which cannot yet be forecast. Nevertheless the writers are of the opinion that difference in age cannot be the answer to the question raised above, as weathering, owing to the higher temperatures prevailing in Indonesia, must be a far quicker process there. In this connection the following facts are perhaps worthy of consideration. The temperatures of the zones in which podzolic soils are found to occur in Indonesia vary from 13 to $20^{\circ} \mathrm{C}$, while those in the zone of the soils of the same name in America vary from $7^{\circ}$ to $10^{\circ} \mathrm{C}$. It can therefore be seen that in Indonesia the average temperatures are about $9^{\circ} \mathrm{C}$ higher. As an increase in temperature of $10^{\circ} \mathrm{C}$ causes a chemical reaction to take place two or three times as quickly as before, in Indonesia a certain stage in soil formation would be reached in only one third to one half of the time required in temperate regions. This is in conformity with the presumed age of the soils, stated above. The writers therefore conclude that the podzolic soils in Indonesia are definitely in the final stage of their development - at any rate, in so far as it is ever possible to speak of a final stage in soil formation, i.e., a stage in which a state of equilibrium exists between soil-forming and disintegrating forces.

Our verdict on the second possibility suggested, viz., the difference in weathering intensity, is based on the hypothesis that the concentration and nature of reacting substances determine the intensity of reaction; the concentrations can also be such that the reaction does not take place at all. The endeavour will be made to prove that, under conditions in Indonesia, the concentration of the liquid percolating through the parent material is much lower than in temperate regions, the nature of these dissolved substances being, for the present, left out of consideration. For this purpose, the assistance of data regarding rainfall and evaporation will have to be invoked. In America the zone of podzolic soils (with the exception of the red-yellow podzolic soils) lies in a belt in which the precipitation/evaporation ratio fluctuates between 1.1 
and 1.5, i.e., averages 1.3 (Transeau, 1905). This ratio is perhaps a little on the high side, as the evaporation index used represents evaporation from a free water surface and not the evapotranspiration of the natural vegetation. In Indonesia the precipitation/evaporation ratio is entirely different. Exact data regarding the evapotranspiration there may be found in a publication by Coster (1937). He states that a mountain forest in West Java evaporates about $860 \mathrm{~mm}$ of water per year. As Tapanuli likewise has no specific dry season in which respect the climate there is comparable with that of West Java, a fact which is also expressed in the same forest composition - its evapotranspiration will be almost the same. In East Java the climate is rather different (dry season), as is shown by the somewhat different forest composition (e.g., absence of Altingia excelsa), which means that the evapotranspiration will possess another value, probably a higher one. It therefore seems justifiable to assume that the mountain soils in Indonesia are formed in climates with a rainfall/evapotranspiration ratio ranging from 3 to 6 . Accordingly, a value is found which differs strongly from that in the relevant zone in America. From this, the important conclusion may be drawn that dilution of the decomposition products (in particular those from fallen leaves) is much greater in Indonesia than in America, as a result of which weathering will differ in intensity in the two regions. The thesis advanced here gives an explanation, at any rate in part, for the fact that the same soils can be developed on not very basic parent materials as on strongly basic materials, owing to differing climatic conditions.

Another question concerns the presumed nature of the weathering agent. A basis for discussion is provided by the $\mathrm{C} / \mathrm{N}$ ratio of the organic matter content of the various horizons of the grey-brown podzolic soils in Indonesia and America. Table 15 shows the average $\mathrm{C}$ and $\mathrm{N}$ percentages, together with the $\mathrm{C} / \mathrm{N}$ ratios, in respect of four soils in West Java; of a profile from equatorial Colombia which was classified by JENNY (1948) as "Andino-podzol", but which, in the opinion of the present writers, must be assigned to the "grey-brown podzolic" soils; and of some members of this group in North America (ANDERson and Beyers, 1934).

Table 15. C/N Ratios of Some Grey-Brown Polzolic Soils in the Tropics and in Temperate Regions.

\begin{tabular}{|c|c|c|c|c|c|c|c|c|c|c|c|}
\hline \multicolumn{4}{|c|}{ West Java } & \multicolumn{4}{|c|}{ Andino-podzol } & \multicolumn{2}{|c|}{$\begin{array}{c}\text { Sassafras } \\
\text { series } \\
\text { (average of } \\
\text { ten profiles) }\end{array}$} & \multicolumn{2}{|c|}{$\begin{array}{l}\text { Norfolk } \\
\text { series } \\
\text { (average of } \\
10 \text { profiles) }\end{array}$} \\
\hline Hor. & $\begin{array}{l}\mathrm{C} \\
\mathscr{\%}\end{array}$ & $\begin{array}{l}N \\
\%\end{array}$ & $\mathrm{C} / \mathrm{N}$ & Hor. & $\begin{array}{l}\mathrm{C} \\
\mathscr{\%}\end{array}$ & $\underset{\%}{\mathrm{~N}}$ & $\mathrm{C} / \mathrm{N}$ & Hor. & $\mathrm{C} / \mathrm{N}$ & Hor. & $\mathrm{C} / \mathrm{N}$ \\
\hline $\begin{array}{l}A_{00} \\
A_{1} \\
A_{2} \\
B\end{array}$ & $\begin{array}{r}38.4 \\
18.3 \\
8.53 \\
3.02\end{array}$ & $\begin{array}{l}1.38 \\
0.86 \\
0.42 \\
0.14\end{array}$ & $\begin{array}{l}27.8 \\
21.2 \\
20.3 \\
21.6\end{array}$ & $\begin{array}{c}\mathrm{A}_{0} \mathrm{~A}_{1} \\
\mathrm{~A}_{2} \\
\mathrm{~B} \\
\mathrm{C}\end{array}$ & $\begin{array}{l}25.4 \\
5.47 \\
1.30 \\
0.50\end{array}$ & $\begin{array}{l}1.11 \\
0.30 \\
0.08 \\
0.03\end{array}$ & $\begin{array}{l}22.9 \\
16.6 \\
16.3 \\
16.7\end{array}$ & $\begin{array}{l}\text { A } \\
\text { B } \\
\text { C }\end{array}$ & $\begin{array}{r}11.8 \\
8.0 \\
6.1\end{array}$ & $\begin{array}{l}\mathrm{A} \\
\mathrm{B} \\
\mathrm{C}\end{array}$ & $\begin{array}{r}16.3 \\
12.3 \\
9.1\end{array}$ \\
\hline
\end{tabular}

The table clearly indicates that a distinct correspondence exists between the tropical grey-brown podzolic soils, as the $\mathrm{C} / \mathrm{N}$ ratio in the profile remains almost constant. In the case of the soils of West Java no great difference can 
be observed between the $\mathrm{C} / \mathrm{N}$ ratio of the litter and that of the soil below it. The $\mathrm{C} / \mathrm{N}$ ratio of the same soils in the temperate regions of America decreases distinctly and strongly.

This might possibly be explained as follows. Under tropical conditions, aeration being very good, no humification worth mentioning occurs, but, instead, strong decarboxylation is likely to take place with concomitant, simultaneous nitrification, and consequently the remaining organic matter will continue to keep the same composition ${ }^{5}$ ). This opinion regarding a virtually complete oxidation of the organic matter is supported by Profile IV where, owing to deforestation, which took place about 25 years ago, the organic $\mathrm{C}$ content of the top layer has declined from about $15 \%$ to $1 \%$. Accordingly, the conclusion presents itself that the organic matter is almost completely decomposed to $\mathrm{CO}_{2}, \mathrm{H}_{2} \mathrm{O}$, and $\mathrm{HNO}_{3}$, after which these substances percolate through the ground. The weathering agent in the tropics must be water containing chiefly $\mathrm{CO}_{2}$, as the nitric acid content cannot be a significant factor in weathering, owing to the low $\mathrm{N}$ content of the organic matter and the high rainfall.

In temperate regions the organic matter fares quite differently. There, aeration of the ground is most certainly much less, as a temporary anaerobic condition arises in winter, under the covering of snow. Oxidation of organic matter will therefore be less intensive, and other reactions will occur, whereby other compounds will be formed - a fact which finds expression in an altered $\mathrm{C} / \mathrm{N}$ quotient. The ratio is smaller, which indicates that products richer in $\mathrm{N}$ are formed, for instance humic acids. As, moreover, the rainfall is much less than under tropical conditions, the soil solution will contain a relatively high concentration of humic acids, from which it follows that the weathering agent, under temperate climatic conditions, is a fairly strong solution of organic acids.

The above enables a conclusion to be drawn which can be represented by the following table.

\begin{tabular}{|c|c|c|c|}
\hline \multicolumn{2}{|c|}{ Climate $\stackrel{+ \text { litter }}{\longrightarrow}$ weathering agent } & \multicolumn{2}{|c|}{+ parent material } \\
\hline $\begin{array}{l}\text { Temperate: } \\
\text { temp. } 7-10^{\circ} \mathrm{C} \text {; } \\
\text { Rainfall/ } \\
\text { evaporation : } \\
1.1 \text { to } 1.5\end{array}$ & $\begin{array}{l}\text { relatively concen- } \\
\text { trated solution of } \\
\text { organic acids }\end{array}$ & $\begin{array}{l}\text { basic to } \\
\text { calcareous } \\
\text { rock }\end{array}$ & $\begin{array}{l}\text { grey-brown podzolic } \\
\text { soil }\end{array}$ \\
\hline $\begin{array}{l}\text { Temperate } \\
\text { to warm : } \\
\text { temp. } 13-20^{\circ} \mathrm{C} \text {; } \\
\text { Rainfall/ } \\
\text { evaporation: } \\
3 \text { to } 6\end{array}$ & $\begin{array}{l}\text { diluted solution } \\
\text { of carbonic acid }\end{array}$ & $\begin{array}{l}\text { intermediary } \\
\text { rock }\end{array}$ & $\begin{array}{l}\text { (tropical) grey- } \\
\text { brown podzolic } \\
\text { soil }\end{array}$ \\
\hline
\end{tabular}

Similarly, the following table can then be compiled for the origin of the brown forest soil under both types of climatic conditions :

5) The fact that the $\mathrm{C} / \mathrm{N}$ ratio of the litter is different from that of the organic matter in the profile is because the organic matter in soil is largely derived from roots. 


\begin{tabular}{|c|c|c|c|}
\hline Climate $\ldots+1$ & $\rightarrow$ weathering agent & $\stackrel{+ \text { parent material }}{\longrightarrow}$ & soil group \\
\hline $\begin{array}{l}\text { Temperate : } \\
\text { temp. } 7-10^{\circ} \mathrm{C} \text {; } \\
\text { Rainfall/ } \\
\text { evaporation : } \\
\text { l.1 to } 1.5\end{array}$ & $\begin{array}{l}\text { relatively concen- } \\
\text { trated solution of } \\
\text { organic acids }\end{array}$ & $\begin{array}{l}\text { basic and } \\
\text { strongly } \\
\text { calcareous rock }\end{array}$ & $\begin{array}{l}\text { brown forest } \\
\text { soil }\end{array}$ \\
\hline $\begin{array}{l}\text { Temperate } \\
\text { to warm: } \\
\text { temp. } 13-20^{\circ} \mathrm{C} \text {; } \\
\text { Rainfall/ } \\
\text { evaporation: } \\
3 \text { to } 6\end{array}$ & $\begin{array}{l}\text { diluted solution } \\
\text { of carbonic acid }\end{array}$ & $\begin{array}{l}\text { intermediarily } \\
\text { basic rock }\end{array}$ & $\begin{array}{l}\text { (tropical) brown } \\
\text { forest soil }\end{array}$ \\
\hline
\end{tabular}

One important point emerges from this, viz., the fact that in the tropics, at altitudes between 700 and 2000 metres, weathering admittedly takes place rapidly, but much less intensively than in temperate regions.

The hypothesis proposed may perhaps also furnish an explanation for the differing $\mathrm{Al}_{2} \mathrm{O}_{3} / \mathrm{Fe}_{2} \mathrm{O}_{3}$ ratios of the clay. Table 16 shows the $\mathrm{Al}_{2} \mathrm{O}_{3} / \mathrm{Fe}_{2} \mathrm{O}_{3}$ ratios in a grey-brown podzolic soil in West Java and in America, respectively (Beyers, Alexander and Holmes, 1935).

Table 16. The molar $\mathrm{Al}_{2} \mathrm{O}_{3} / \mathrm{Fe}_{2} \mathrm{O}_{3}$ ratio in a grey-brown podzolic soil in West Java and in north-east America (Miami silt loam), respectively.

\begin{tabular}{c|c|c|c}
\multicolumn{2}{c|}{ West Java } & \multicolumn{2}{c}{ Miami silt loam } \\
\hline Hor. & $\mathrm{Al}_{2} \mathrm{O}_{3} / \mathrm{Fe}_{2} \mathrm{O}_{3}$ & Hor. & $\mathrm{Al}_{2} \mathrm{O}_{3} / \mathrm{Fe}_{2} \mathrm{O}_{3}$ \\
\hline & & & \\
\hline $\mathrm{A}_{1}$ & 4.75 & $\mathrm{~A}_{1}$ & 4.68 \\
$\mathrm{~A}_{2}$ & 5.85 & $\mathrm{~A}_{2}$ & 4.55 \\
$\mathrm{~B}_{1}$ & 7.47 & $\mathrm{~B}$ & 3.19 \\
$\mathrm{~B}_{2}$ & 8.25 & $\mathrm{C}$ & 3.38 \\
$\mathbf{C}$ & 11.5 & & \\
\hline
\end{tabular}

Whereas in tropical grey-brown podzolic soil aluminium is more mobile than iron, the reverse is the case in the same soil group in temperate climates. Various investigators have carried out observations regarding the movement of the sesquioxides in the podzol profile. AArNio (1913), for instance, studied the precipitation of ferric hydroxide and aluminium hydroxide soils by humate solutions, and found that, in the case of a ratio of $\mathrm{Fe}_{2} \mathrm{O}_{3}$ to humus of $1: 0.2$ to 1 : 2.8 , precipitation occurred, whereas the $\mathrm{Al}_{2} \mathrm{O}_{3}$ /humus ratio varied from $1: 1$ to 1 : 30 when precipitation occurred. This means that ferric oxide is more mobile than aluminium oxide; for, at least 30 times as much humus as $\mathrm{Al}_{2} \mathrm{O}_{3}$ has to be present in order to dissolve aluminium colloidally, whereas much less is necessary in the case of $\mathrm{Fe}_{2} \mathrm{O}_{3}$. As, moreover, the $\mathrm{Al}_{2} \mathrm{O}_{3}$ content of the soils is almost always greater than the $\mathrm{Fe}_{2} \mathrm{O}_{3}$ content, the conditions for rendering aluminium mobile become even more unfavourable. Jones and Wilcox (1929), and Gallagher (1942), found that hydroxy acids bound the sesquioxides complex. As the complex ferric humate compounds are more 
soluble than the complex aluminium humate compounds, this also indicates a greater degree of mobility of iron in the profile here.

BloOMfield $(1953,1954)$ also found in his experiments that the iron and aluminium complexes were bound by extracts of the leaves and bark of various kinds of trees. A further conclusion from his data is that from twice to eight times as much iron as aluminium was bound by these extracts, which again prompts the conclusion of a greater mobility on the part of the iron. The results of these investigations give a sufficiently exact idea, at any rate provisionally, of the trend of the $\mathrm{Al}_{2} \mathrm{O}_{3} / \mathrm{Fe}_{2} \mathrm{O}_{3}$ quotient in podzolic soils under temperate conditions, in which, admittedly, the weathering agent consists of organic acids.

When the climatic circumstances vary from temperate to warm, water containing carbonic acid is the weathering agent, as has been demonstrated above. In order to obtain some insight into the mobility of iron and aluminium, it will be necessary to have data concerning the solubility of ferric hydroxide and aluminium hydroxide in water. HoDGMAN (1945) gives for their solubility products the following values : at $18^{\circ} \mathrm{C}$ : ferric hydroxide, $1.1 \times 10^{-36}$; aluminium hydroxide, $1.1 \times 10^{-15}$. Aluminium hydroxide thus appears to be considerably more soluble in water than ferric hydroxide. This is undoubtedly also the case in water containing carbonic acid, and it therefore follows that, under temperate to warm climatic conditions with high rainfall, such as occur in the tropics at altitudes between 700 and $2000 \mathrm{~m}$, aluminium will be more mobile than iron, as is expressed by an increase in the molar $\mathrm{Al}_{2} \mathrm{O}_{3} / \mathrm{Fe}_{2} \mathrm{O}_{3}$ ratio in the profile.

Of course, transitional forms exist between the two forms of weathering, for instance in cases in which a solution containing $\mathrm{CO}_{2}$ possesses a low concentration of organic acids. The result ought then to be an equally great mobility of iron and aluminium and a constant $\mathrm{Al}_{2} \mathrm{O}_{3} / \mathrm{Fe}_{2} \mathrm{O}_{3}$ ratio in the profile. The brown podzolic soils of Tapanuli are, perhaps, an example of this.

As regards the molar $\mathrm{SiO}_{2}$ /sesquioxides ratios, it is clear that we have here to do with podzolic weathering, as has already been said on p. 201. It is, however, remarkable that the molar silicic acid/sesquioxide quotients of the clay fractions of the $A_{2}$ and $B_{1}$ horizons are very much smaller than those of the $A_{1}$ horizon, especially in those cases in which organogenous silicic acid occurs in the sand fraction. The organogenous silicic acid, which is amorphous, very probably originates from the forest litter, which possesses a high content of $\mathrm{SiO}_{2}$. This can be seen from an analysis of the forest litter of Profile II (West Java) (see Table 17).

Table 17. Composition of Forest Litter.

\begin{tabular}{l|c|c|c|c|c|c|c|c}
\hline & $\underset{\%}{\mathrm{Ash}}$ & $\underset{\%}{\mathrm{SiO}_{2}}$ & $\underset{\%}{\mathrm{Al}_{2} \mathrm{O}_{3}}$ & $\underset{\%}{\mathrm{Fe}_{2} \mathrm{O}_{3}}$ & $\underset{\%}{\mathrm{P}_{2} \mathrm{O}_{5}}$ & $\underset{\%}{\mathrm{CaO}}$ & $\begin{array}{c}\mathrm{MgO} \\
\%\end{array}$ & $\begin{array}{c}\text { Rest } \\
\%\end{array}$ \\
\hline $\begin{array}{l}\text { Constituents as percent- } \\
\text { ages of the absolute con- } \\
\text { tent of dry matter } \cdots\end{array}$ & 7.35 & 3.60 & 1.13 & 0.38 & 0.10 & 0.60 & 0.36 & 1.18 \\
$\begin{array}{l}\text { Constituents as percent- } \\
\text { ages of the ash content }\end{array}$ & - & 48.0 & 15.3 & 5.06 & 1.62 & 8.10 & 4.96 & 16.96 \\
\hline
\end{tabular}


The silicic acid from the organic matter will find its way not only into the sand fraction, but certainly also into the clay fraction, where it will cause high $\mathrm{SiO}_{2}$ /sesquioxide ratios.

As regards the mineralogical composition of the clay fraction, the present writers entirely agree with Simonson (1949), who concludes that no distinction can be made between red-yellow podzolic and grey-brown podzolic soils on the basis of clay mineral content. This also applies to the brown podzolic and brown forest soils. It can, however, be said that in the temperate regions illite is constantly found with admixtures of kaolinite and montmorillonite. In the profiles examined, the following occur under tropical conditions, viz. : kaolinite, halloysite-2 (and -4), gibbsite, $a$-cristobalite, montmorillonite and quartz. The occurrence of these minerals is largely determined by the nature of the parent material. No montmorillonite occurs in the Tapanuli profiles, whereas the profiles of Java generally do contain montmorillonite. This is in conformity with the view of the genesis of these soils given by us. No further conclusions regarding genesis can be drawn here, as the determination of the percentual composition of the clay fraction is highly inaccurate, owing to the presumed presence of a high percentage of amorphous material (see p. 203).

Although MCCALEB (1954), on the basis of petrographic observations carried out on grey-brown podzolic soils, considers it justifiable to conclude that clay particles were transported to the $B$ horizon (mechanical illuviation), no further explanations are to be found in the literature of the subject for the fact that the clay content of brown forest soils decreases with depth; that the clay content of brown podzolic soils remains more or less constant; and that the clay content of grey-brown podzolic soils distinctly increases. Since this investigation likewise failed to produce points of departure for explaining these phenomena it is only remarked here that, in order to complete our understanding of the mechanism of formation of the profiles discussed, exact observations are required regarding the permeability of the parent material, the behaviour during weathering of volcanic glass and the minerals which are easily vulnerable to attack, and possible "new formation" of clay particles in the $\mathrm{B}$ horizon.

\section{BIBLIOGRAPHY}

Aarnio, B.: Int. Mitt. Bodenk. 3 (1913), 131.

Allison, L. E. : Soil Sci. 40 (1935), 311.

Anderson, M. S. \& H. G. Beyers : Soil Sci. 38 (1934), 121.

BAAK, J. A. : Landbouw 20 (1948), 269.

- - : Comm. of the Gen. Agric. Exp. Station, 83 (1949).

Baldwin, M. : Proc. 1st. Int. Congress of Soil Sci. (Comm. V) (1927), 276.

- - : Yearbook of Agriculture. Soil and Men (1938).

Baren, F. A. van \& H. Kiel: Journ. of Sed. Petr. 20 (1950), 185.

BemMelen, R. W. van: The Geology of Indonesia. The Hague (1949).

Berlage, H. P.: Verh. 37, Dept. Verk., Energie en Mijnw., Met. en Geoph. Dienst, Kon. Magn. Obs. Batavia (1949).

Beyers, H. G., L. T. Alexander \& R. S. Holmes : U.S. Dept. Agr. Techn. Bull. 484 (1935).

Bmweld, O. W. \& J. B. PAge : Soil Sci. Soc. Amer. Proc. 15 (1951), 314.

Brltz, H. \& W. Bictz: Ausführung quantitativer Analysen (1947).

Blanck, E. : Handbuch der Bodenlehre, Berlin (1932).

Bloksma, A. H. : Het suspensie effect. Thesis. Amsterdam (1955).

Bloomfield, C. : J. Soil Sci. 4 (1953), pp. 5, 17.

- - J. Soil Sci. 5 (1954), pp. 39, 46, 50. 
Chandler, R. F.: J. Agric. Res. 59 (1939), 491.

Cline, M. G. : Soil Sci. 68 (1949), 259.

Coster, С.. : Tectona 30 (1937), 2.

Faust, G. T. \& E. Callaghan : Bull. Geol. Soc. Amer. 59 (1948), 11.

Gallagher, P. H. : Proc. Roy. Irish Acad. 48B (1942), 213.

Gardner, D. R. \& E. P. Whiteside : Soil Sci. Soc. Amer. Proc. 16 (1952), 137.

Hannawalt et al.: A.S.T.M. Diffraction Cards + First and Second Suppl., Philadelphia (1950).

HARDON, H. J. : Natuurk. Tiidschr. 96 (1936), 25.

Hodgman, CH. D.: Handbook of Chemistry and Physics, 29th Edition, Cleveland, Ohio (1945).

JENNY, H. : Soil Sci. 66 (1948), 5.

Jones, H. T. \& J. S. WIlcox : J. Soc. Chem. Ind. 48 (1929), 304.

KNoch, K. : in Blanck's Handbuch der Bodenkunde, Pt. 2, I (1922).

Lorenz, N. von: Z. Analyt. Chemie 46 (1907), 191.

Lyford, W. H. : Soil Sci. Soc. Amer. Proc. 11 (1947), 486.

- - : Soil Sci. Soc. Amer. Proc. 16 (1952), 231.

McCaleb, S. B. \& M. G. Clune: Soil Sci. 70 (1950), 315.

- - : Soil Sci. 77 (1954), 319.

MoHr, E. C. J. : De Bodem van Java en Sumatra, Amsterdam (1922).

$--\&$ F. A. van Baren : Tropical Soils. The Hague and Bandung (1954).

Nikiforoff, C. C. : Soil Sci. 44 (1937), 447.

Nygard, I. J., P. R. McMiller \& F. D. Holle : Soil Sci. Soc. Amer. Proc. 16 (1952), 123.

PARrish, W. \& B. W. Irwin : Data for X-ray Analysis, Vol. I (1953).

Reinhardt, C. : Chem. Ztg, 13 (1889), 323.

Robrsson, G. W. : Soils, their Origin, Constitution and Classification. London, Third Edition (1949).

Rummelen, F. F. F. E. van \& R. Rachmat Hardjosoesastro: J. Sci. Res. (O.S.R. News), 8-9 (1952), 178.

Rummelen, F. F. F. E. van: (a) Landbouw 25 (1953), 225.

- - : (b) Landbouw 25 (1953), 237.

- - : (c) Landbouw 25 (1953), 347.

Schauffelderger, P.: Schweiz. Min. und Petr. Mitt. 30 (1950), 238.

Schuchert, C. \& C. O. Dunbar : A Textbook of Geology, Part II : Historical Geology. New York, London (1941).

SchuYlenborgh, J. van: Neth. J. of Agr. Sci. 2 (1954), 50.

Senstius, M. W. : Soil Research 2 (1930), 10.

Simonson, R. W.: Soil Sci. Soc. Amer. Proc. 14 (1950), 316.

StobBe, P. C. : Soil Sci. Soc. Amer. Proc. 16 (1952), 81.

Swanson, C. L. W., A. E. Shearin \& G. A. Bourbeau : Soil Sci. Soc. Amer. Proc. 16 (1952), 203.

Transeau, E. N. : Am. Naturalist 39 (1905), 875.

Tsuneo Tamura \& C. L. W. Swanson: Soil Sci. Soc. Amer. Proc. 18 (1954), 148.

Zimmermann, Cl.: Ber. Deutsch. Chem. Ges. 14 (1881), 779. 


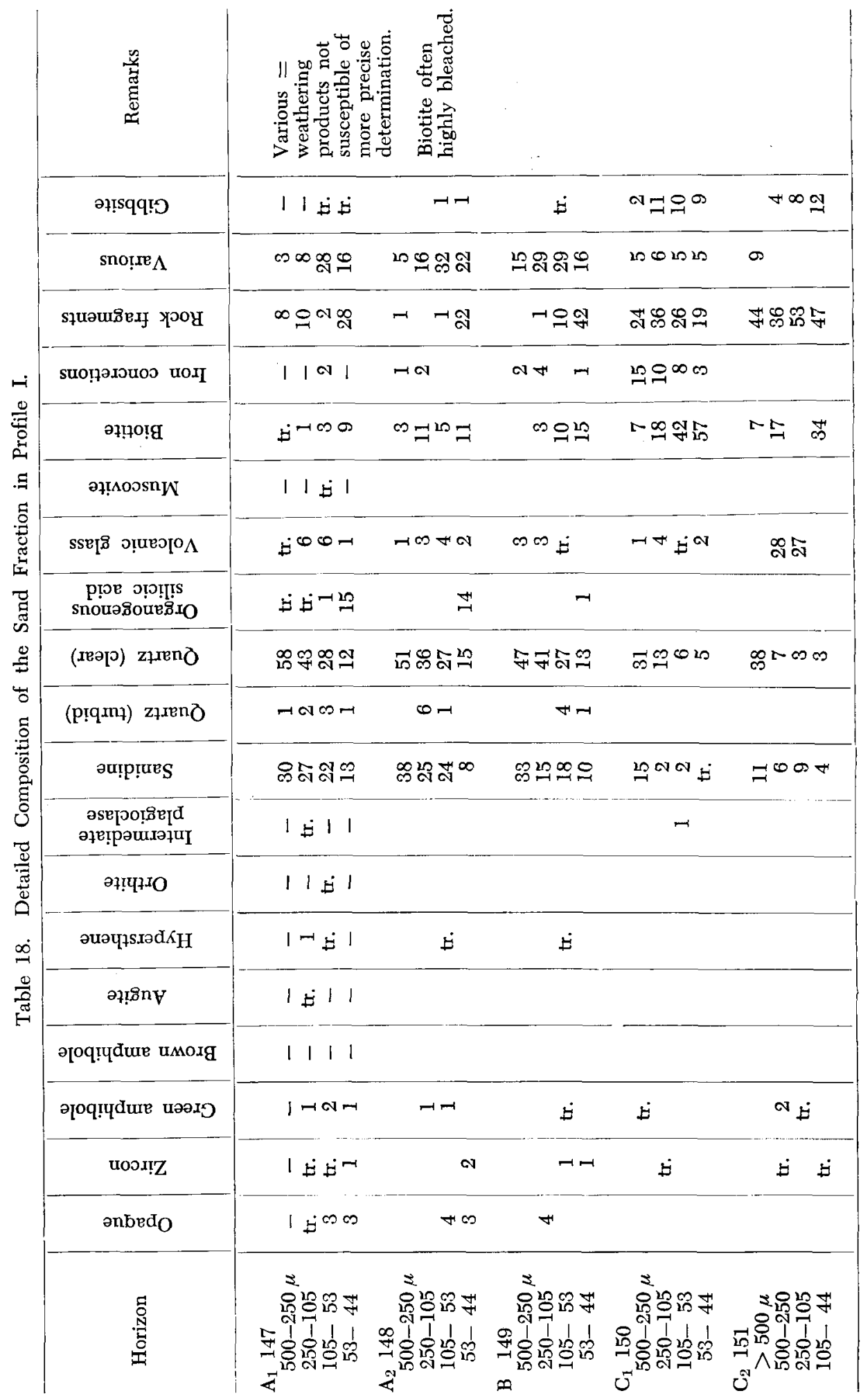




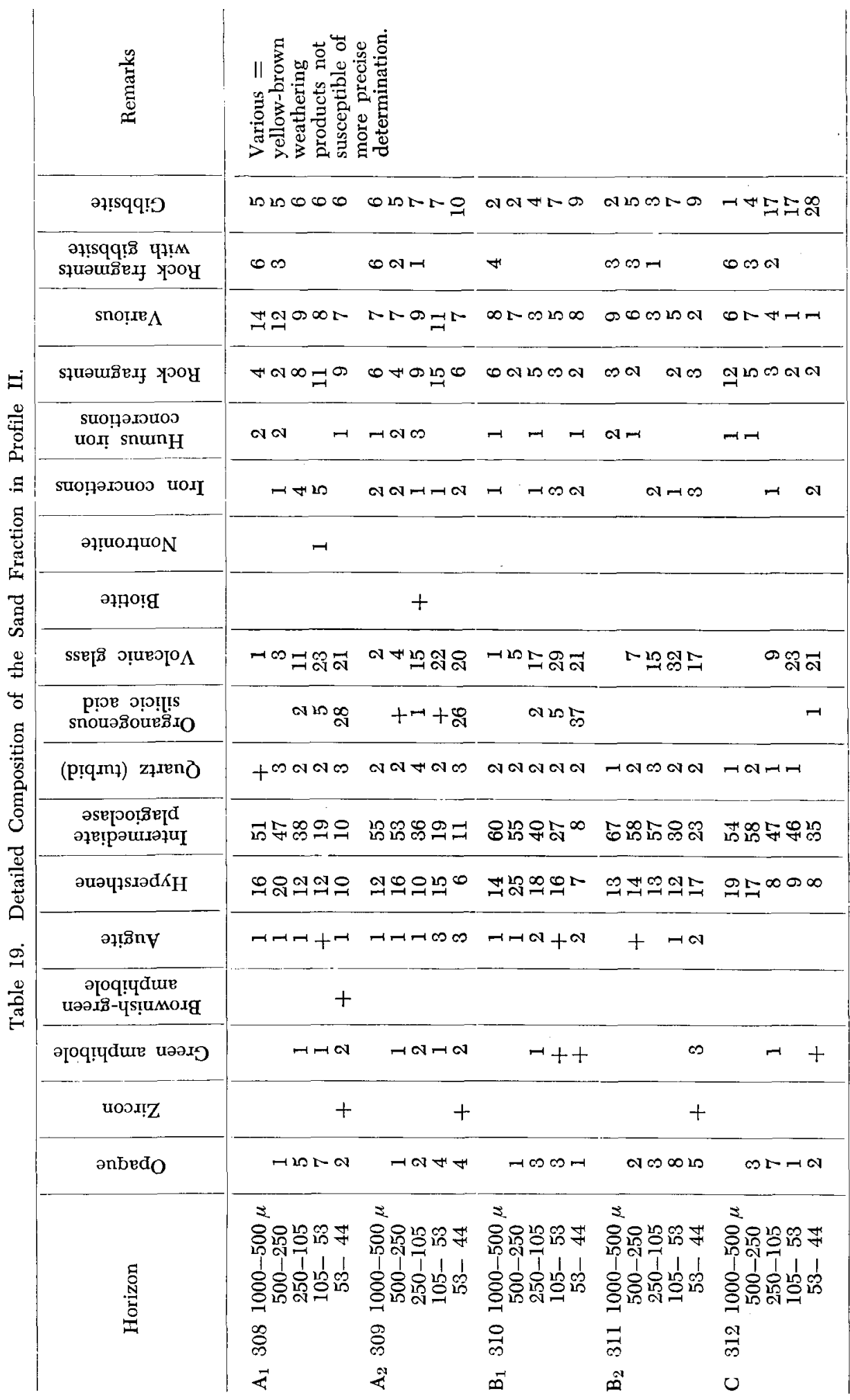




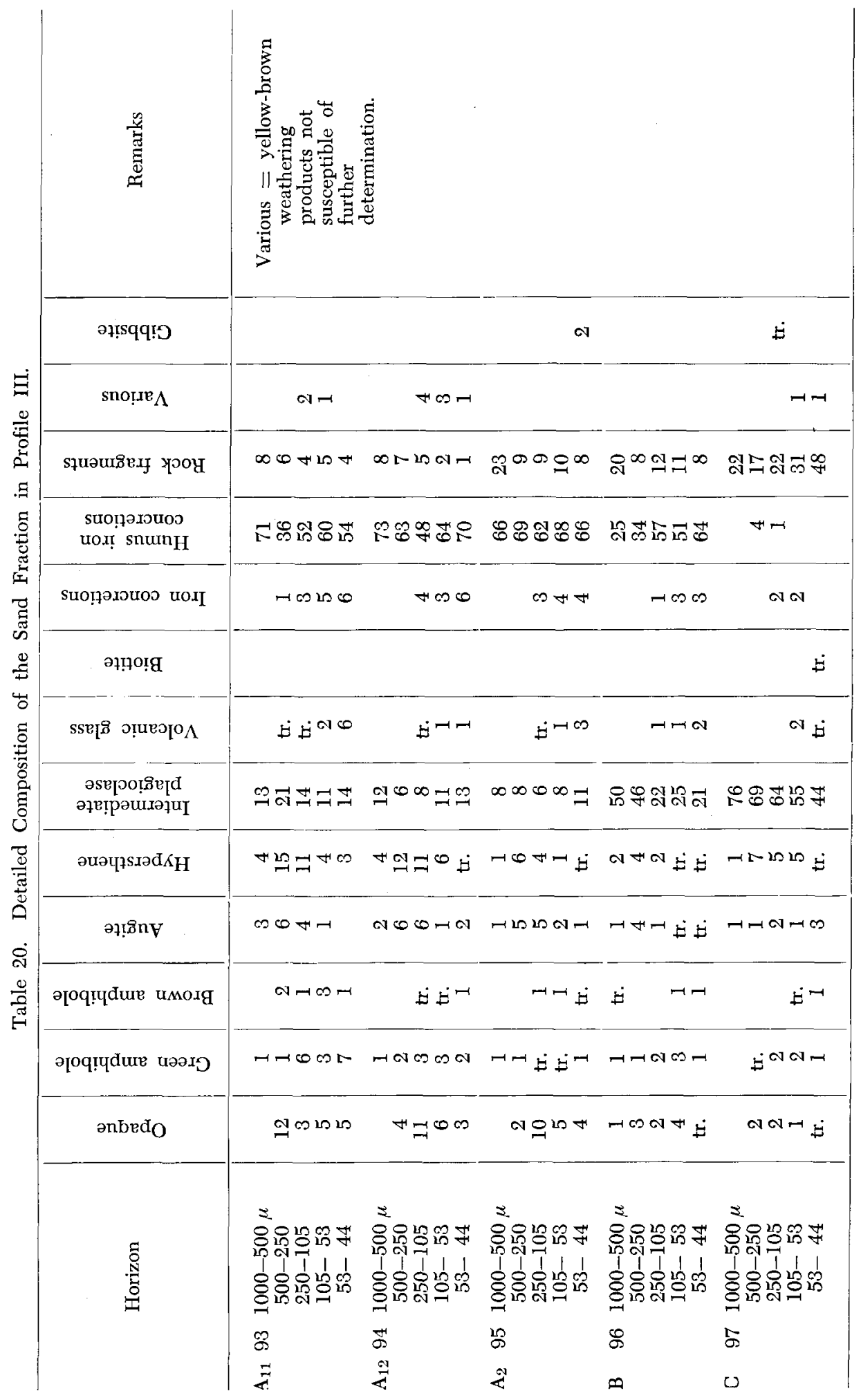




\begin{tabular}{|c|c|c|c|c|c|}
\hline 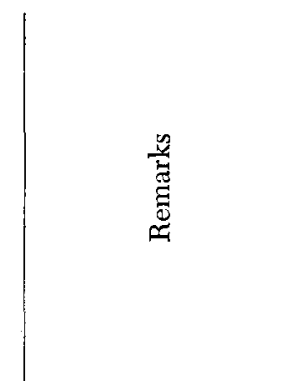 & 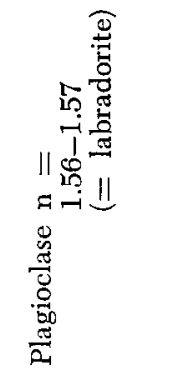 & & & & \\
\hline $\operatorname{snoțx} \Lambda$ & & $-r$ & $\rightarrow$ & $\omega \dot{H}$ & - \\
\hline 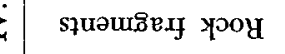 & 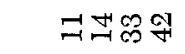 & 점요 & $\because$ & 육봉워 & 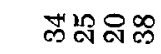 \\
\hline $\begin{array}{l}\text { suop̧ə.jouos } \\
\text { [ย.əu!W }\end{array}$ & セみみウ & ஈーの & ง & 든엉 & 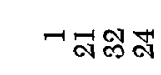 \\
\hline әңฺุo.quoN & -1 & $\dot{B}$ & - & - & \\
\hline 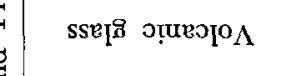 & 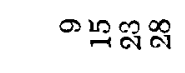 & 코요 & 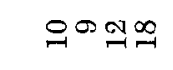 & 표 & a을 \\
\hline 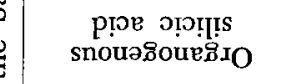 & $\neg \infty \infty$ & $B_{0}$ & $-\infty$ & N & ロー \\
\hline 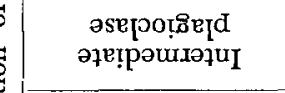 & ํํㄱ역 & దี & 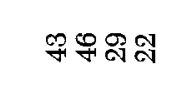 & 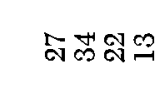 & 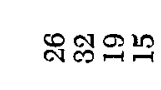 \\
\hline әиวчұłsıəd $\kappa \mathbf{H}$ & 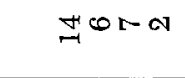 & $\infty \theta_{-1}$ & ザルー & סט מו מוג & 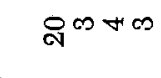 \\
\hline әu!̣ı!!O & & & & $r$ & -1 \\
\hline əج!ฺกท & $\vec{J}$ & Ho & N্নে & 命みみ & 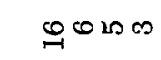 \\
\hline әроф!̣dure umoxg & & & $\dot{B}$ & & \\
\hline 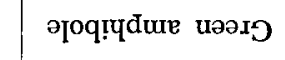 & $a r-r$ & $\dot{b}^{N \leadsto N}$ & $\rightarrow \infty-\infty$ & -NO & カーーの \\
\hline ә[!̣ny & & & & $\dot{5}$ & \\
\hline әnbedo & $\infty x-\infty$ & -09 & 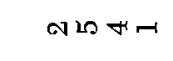 & $\rightarrow \rightarrow \infty$ & Nल \\
\hline 胥 & 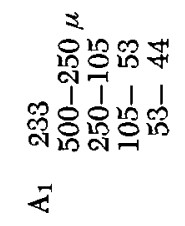 & 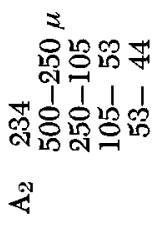 & 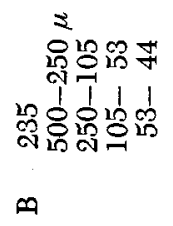 & 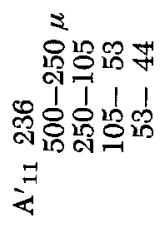 & 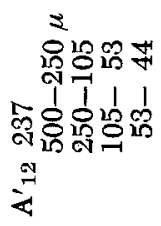 \\
\hline
\end{tabular}

